\title{
SOUTH PACIFIC COMMISSION
}

The impact of extended jurisdiction on fisheries management

in the central and western tropical Pacific Ocean and the need for a regional fisheries agency.

R. E. Kearney 


\section{Introduction}

2. The Impact of Extended Jurisdiction to 200 Nautical Miles on National Fisheries Policies

2.1 The principles involved

2.2 The nature of the increase in resource control by coastal states

2.2.1 The rights of coastal states to increase their control over the harvesting of the living resources within their respective exclusive economic zones

2.2.2 The obligations of coastal States to promote optimum resource utilization from these areas

2.2.3 The obligations of nationals fishing in an exclusive economic zone, other than their own

2.2.4 The need to conserve the fishery resource base

3. The Regional Fish Resources 3

3.1 Total fisheries resources 3

3.1.1 Highly migratory species 4

3.1.2 Offshore deepwater fisheries resources 4

3.1 .3 Coastal fisheries 5

3.2 Resources and fisheries affected by extended jurisdiction 5

3.2.1 Tuna resources exploited in surface fisheries $5-6$

3.2.2 The long-line caught tunas and billfish 7

3.2.3 Marine mammals 7
3.2.3.1 Whales
$7-8$
3.2.3.2 Dolphins
8
3.2.3.3 Dugong
8
3.2.4 Marine turtles

4. Management of Living Oceanic Resources and the need for a Regional Approach

4.1 The objectives of management 9

4.1.1 Maintenance of the resources 9

4.1.2 Maximization of socio-economic benefits $9-10$

4.1.3 National and international political objectives 10 
4.2.1 The need for regional fishery statistics 11

4.2.2 The highly migratory nature of the resources 11

4.2.3 The mobility of the fleets harvesting the resources 11

4.2.4 The variable distribution of the resources 11

4.2.5 The variable vulnerability of the species concerned 11

4.2.6 The dependence of the resources of the region on common spawning or nursery grounds

4.2.7 Interaction between surface and long-line fisheries $12-13$

4.2.8 Common interest of developing countries of the region 13

4.2.9 Added power of a common interest block 13

4.2.10 Prevention of duplication of research effort 13

4.2.11 Minimizing surveillance effort 13

4.2.12 The need to ensure access to the fishing grounds 14

4.3 Consideration of the principles outlined in the UN Law of the sea texts

5. The Role of a Regional Fisheries Body

5.1 The possible tasks of a regional fisheries body 15

5.1 .1 Resource assessment

5.1.1.1 Fishing statistics

5.1.1.2 Biology and behaviour of the important fish species

5.1.1.3 Stock description

5.1.1.4 Environmental description

5.1.2 Economic appraisal of the fisheries

5.1.3 Management of $\mathrm{f}$ isheries resources

5.1.4 Determination of resource ownership and/or resource

5.1.5 Licensing of foreign vessels and the redistribution of revenue

5.1.5.1 Some alternatives for licensing

$21-22$

5.1.5.2 Fees or taxes payable

$22-23$

5.1 .6 Surveillance

5.2 A possible approach to the development of a regional fisheries body

6. The Membership, Structure and Financing of a Reginnal

\section{Fisheries Body}

6.1 Membership

6.2 Structure

6.3 Financing 


\section{List of Tables and Figures}

Table 1 Estimated total catches of all tuna and tuna-like species in selected statistical areas (Figures modified from W.L. Klawe, Inter-American Tropical Tuna Commission, 1976, Personal Communication).

Table 2 Nominal total fish and tuna catches in 1974 by

the countries and territories in the South Pacific Commission area. (From FAO, 1975. Previously published by Kearney, 1976a).

Table 3 Annual total catch and catch rates by the Papua New Guinean skipjack fleet. (From Department of Primary Industry, Papua New Guinea, 1977).

Table 4 Annual total catch and catch rates by the Solomon Islands' skipjack fleet. (From the Ministry of Natural Resources, Solomon Islands, unpublished data).

Table 5 List of highly migratory species. (From Part II of RSNT, 1976).

Table 6 Estimated budget for a secretariat of a regional fisheries agency (Phase 1). Modified from IPFC (1976).

Fig. 1 The core area of the central and western tropical Pacific Ocean.

Fig. 2 The demarcation of FAO statistical areas in the Pacific Ocean.

Fig. 3 Approximation of areas of 200 mile exclusive economic zones.

Fig. 4 Recent fluctuations in albacore prices on Japanese and United States markets (modified from Kearney 1975b).

Fig. 5 Areas of maximum whale captures from the south western Pacific in the 19 th century. (From Lever, 1964). 


\section{Introduction}

More than 98 per cent of the central and western tropical Pacific region is water. It is not surprising then that this oceanic area yields a major share of the natural resource harvest, and that the catch from the region of highly migratory species alone realizes approximately $\$$ US $300,000,000$ annually.

By the end of 1977 most, if not all, of the world's major fishing nations will have increased their control over the oceans surrounding them by the establishment of 200 mile exclusive economic zones. Acceptance of similar zones in the central and western tropical Pacific will bring more than $20,000,000 \mathrm{sq} . \mathrm{km}$. of this area under the control of the Island States, effectively ensuring that the harvesting and managing of the oceanic resources of the entire region are the responsibility of the developing countries and territories of the area. On the one hand the Island States have the opportunity to benefit substantially from the harvesting of fish in the zone under their jurisdiction and, on the other, they must accept the responsibility of ensuring that the resource is rationally managed and that yields are maintained at optimum leve1s.

As universal acceptance of 200 mile exclusive economic zones will permanently influence fisheries development and management, it is essential that the countries and territories of the region be aware of all available development options before management policies are finalized. Clearly the common interests of the developing Island States and the sharing of common resources, particularly the highly migratory ones, necessitate close cooperation in the formulation of all fisheries policies. A single fisheries agency to investigate the regional implications of future fisheries management and to advise member Governments on development options is clearly indicated.

In the eastern Pacific and Atlantic Oceans international commissions for studying and managing the highly migratory tuna resources have been operating since 1950 and 1966 respectively. The present 1 ack of adequate data on the massive catches of tunas from the central and western Pacific ocean endorses the need for a similar fisheries body for this area.

At the October 1976 Meeting of the South Pacific Forum in Suva, Fiji, (South Pacific Forum, 1976) the members

(a) declared their intention to establish 200 mile exclusive economic zones at appropriate times and after consultation with one another;

(b) decided to (i) harmonize fisheries policy in the region; (ii) adopt a coordinated approach in their negotiations with distant water fishing countries;

(c) decided in principle to establish a South Pacific fisheries agency to promote the conservation and rational utilization of the fish stocks of the region.

Subsequently the Sixteenth South Pacific Conference, appreciating the implications to the Island nations of the outcome to the Sixth Session of the Third Law of the Sea Conference to be held in New York in May 1977, agreed that the Island members of the South Pacific Conference fully endorsed the spirit and intention of the Forum declaration (South Pacific 
Conference 1976). The inevitability of extended fisheries jurisdiction in most regions of the world by the end of 1977, regardless of the outcome of the May meeting in New York, stresses the urgency of determining fisheries policy.

As the decisions of the South Pacific Forum, endorsed by the South Pacific Conference, deal exclusively with the coordination of fisheries policy in the region, throughout this paper I have considered only living aquatic resources.

2. The Impact of Extended Jurisdiction to 200 Nautical Miles on National Fisheries Policies

\subsection{The principles involved}

Members of the South Pacific Forum attending the Suva Meeting (October 13-14, 1976) to discuss Law of the Sea questions affirmed their common interest in securing the adoption of a new and comprehensive Convention on the Law of the Sea and agreed that they would continue to work together at the Third United Nations Conference on the Law of the Sea to complete the Convention as soon as possible. These policies were endorsed by the Island members of the Sixteenth South Pacific Conference (Noumea, October 20-29, 1976). As no country, or group of countries and territories, from the central and western tropical Pacific region has indicated any intention to act in a manner contrary to the principles adopted in a universal Law of the Sea Convention, the principles and basic philosophy expressed in the Revised Single Negotiating Text (1976)(hereinafter referred to as RSNT, 1976) have been quoted and used as guidelines throughout this paper.

\subsection{The nature of the increase in resource control by coastal States}

One accepted principle of the Law of the Sea negotiations is that the zone of extended jurisdiction will extend to a distance of "200 nautical miles from the baseline (coastline) from which the breadth of the territorial sea is measured" (Article 45, Part II of the RSNT, 1976). The rights and duties of a coastal State in this exclusive economic zone are defined in Chapter III, Articles 44 through 63 of Part II of the RSNT (1976). The most significant of these articles to a discussion of changes in fisheries policy in the tropical western and central Pacific Ocean are 50, 51 and 53. Throughout those sections of the RSNT relevant to fisheries, four main themes have been stressed:

2.2.1 The rights of coastal States to increase their control over the harvesting of the living resources within their respective exclusive economic zones

The increased rights of coastal States in the exclusive economic zone are clearly defined in Article 44, "(a) Sovereign rights for the purpose of exploring and exploiting, conserving and managing the natural resources, whether living or non-living, of the bed and subsoil and the superjacent waters;". Additionally (Article 50.1) "The coastal State shall determine the allowable catch of the living resource in its exclusive economic zone", and (Article 51.2) "The coastal State shall determine its capacity to harvest the living resources of the exclusive economic zone". 
2.2.2 The obligations of coastal States to promote optimum resource utilization from these areas

Considering the otligations of coastal States, Article 51.1 states "The coastal State shall promote the objective of optimum utilization of the living resources in the exclusive economic zone" and Article 51.2 adds "Where the coastal State does not have the capacity to harvest the entire allowable catch, it shall...give other States access to the surplus of the allowable catch".

2.2.3 The obligations of nationals fishing in an exclusive economic zone, other than their own

The obligations of nationals of other States fishing in the exclusive economic zone are numerous but most importantly include compliance "with the conservation measures and with the other terms and conditions established in the regulations of the coastal State. These regulations shall be consistent with the present Convention and may relate, inter alia, to the following:

(a) Licensing of $\mathrm{f}$ ishermen, fishing vessels and equipment, including payment of fees and other forms of remuneration...

(b) Determining the species which may be caught, and fixing quotas of catch, ...

(e) Specify information required of fishing vessels, including catch and effort statistics and vessel position reports,...

(h) The landing of all or part of the catch by such vessels in the ports of the coastal State;...

(k) Enforcement procedures" (Article 51.4).

2.2.4 The need to conserve the fishery resource base

Article 50.3 endorses the need "to maintain or restore populations of harvested species at levels which can produce the maximum sustainable yields, as qualified by relevant environmental and economic factors, including the economic needs of coastal fishery communities and the special requirements of developing countries".

These four points $(2.2 .1-2.2 .4)$ clearly indicate the increased rights of coastal States, and their responsibility to protect the resource for the benefit of mankind and to actively promote attainment of maximum sustainable yields. Full responsibility for the assessment of the magnitude of the resource rests with the coastal States and there is little doubt that the authority to manage this resource, and to obtain benefit from the harvesting of it, even though part or all of it is harvested by other nationals, is vested in the coastal states.

\section{The Regional Fish Resources}

\subsection{Total fisheries resources}

Hodgkinson (1973) estimated that only approximately 1.8 per cent of the South Pacific Commission area (figure 1) is 1 and. Thus it is not surprising that the living resources of the 30,000,000 square kilometres of ocean included in this area should be of great significance to all peoples of the region. 


\subsubsection{Highly migratory species}

Present fisheries production from FAO statistical area 71 (figure 2) is dominated by the highly migratory tunas and billfishes. The total catch of these fishes exceeded 460,000 tonnes in 1974 (table 1), valued at approximately $\$ U S 250,000,000$ as fresh fish, or in excess of $\$ U S 700,000,000$ in processed forms at the retail level. Fisheries exploiting these species therefore dominate discussions on fisheries resources of regional significance at the present time. Indeed it can be argued that only resources of a highly migratory nature require truly regional, rather than national, consideration (see section 3.2 ).

Some marine mammals which were of great economic significance to the region in the nineteenth century (e.g. southern right, Balaena antipodarum, sperm, Physeter catodon, and humpback whales, Megaptera novaeangliae) and marine turtles, which are known to be wide-ranging even if not strictly highly migratory, could also warrant special consideration as regional resources (see sections 3.2 .3 and 3.2 .4 ).

\subsubsection{Off shore deepwater fisheries resources}

In the central and western Pacific, areas suitable for harvesting bottom-fish resources by conventional means are limited (Kearney 1976a). However, recently developed fisheries for deep water species in other regions of the Pacific Ocean indicate that possibilities for development of fisheries for non-conventional species, or using nonconventional techniques, do need to be considered when regional fisheries policy is determined. In recent years fisheries for alfonsin (Beryx splendens) and pelagic armourhead (Pentaceros richardsoni) have been developed on the seamount chain to the north-west of Hawaii. In this area catch rates of pelagic armourhead by experimental Russian trawlers have been as high as 30 tonnes in 10 minutes and commonly of the order of 20-30 tonnes per 10 to 20 minute tow (Sakiura 1972). Other surveys and commercial fishing using bottom longlines and trawling gear have confirmed the resources of both pelagic armourhead and alfonsin in the north central Pacific (JAMARC 1973, Anon 1976a). The prospects for developing similar fisheries in the more equatorial regions should be investigated as soon as practicable, particularly as the pelagic armourhead has already been proven to be a wide-ranging species (Sasaki 1974). In addition, preliminary reports of favourable catches of deep water species, especially the red snapper, Etelis marshi (James 1977), in seamount areas of the waters adjacent to the Solomon Islands, and the occurrence of numerous presently unfished seamounts in the western Pacific region further suggest potential for the future development of commercial deepwater fisheries.

As little is known of the behaviour and biology of these deepwater species it cannot yet be ascertained if the resources require consideration primarily on a regional basis. Perhaps these resources will come to be regarded as more sedentary or continental shelf species (see Article 65, Part II RSNT 1976) and, as such, may well be adequately covered by national management policies similar to those for coastal fisheries (section 3.1.3). At the present time the developing countries of the central and western tropical Pacific have neither the scientific information necessary to manage these resources nor the vessels and expertise necessary to exploit them. At least in the short-term, then, a regional approach through a common fisheries agency is warranted. 


\subsubsection{Coastal fisheries}

In terms of total fisheries production from the central and western tropical Pacific, coastal fisheries for a great varlety of reef fishes and Inshore pelaglc species are second to fisheries for highly migratory specles. Furthermore, the soclo-economic significance of these fisherles to Pacific Island villagers is in many Instances such as to outweigh in 1mportance the larger export fisheries. In examining the need for regional management of coastal fisheries resources, Kearney (1976a) polnted out that the 1 and masses of the tropical central and western Pacific are, in general, comparatively 1solated islands or archipelagoes which are surrounded by clear, extremely deep ocean. In most cases the transition in depth from shallow, in-shore or lagoon waters is precipitous, with a drop away to depths which of ten exceed 1,000 fathoms in distances from shore of a few miles or even less. The fisherles resources of each of these islands, or at least of each archipelago, can thus in the main be considered as discrete units which are not appreciably influenced by $f$ ishery-induced or natural fish mortalities in other areas; therefore in most cases the actual management of such resources should be handled at national rather than regional level. Furthermore, as the South Pacific Commission currently covers the regional aspects of in-shore fisheries, additional regional consideration is not required.

\subsection{Resources and fisheries affected by extended jurisdiction}

Extension of furisdiction by coastal States from the presently generally accepted 12 mile territorial sea to include a 200 mile exclusive economic zone will incorporate more than 20,000,000 square kilometres of the tropical central and western Pacific, currently regarded as high seas, into the areas of jurisdiction of the coastal States (see figure 3). The only living resources of significance presently harvested from this additional area are the highly migratory tunas and billfishes. While detailed catch figures have not been compiled from the core area previously discussed (figure 1), comparison with FAO statistical area 71 (figure 2) which has substantial overlap with the core area, indicates that total catches of tuna and billfish approached 400,000 tonnes in 1974 from areas outside the 12 mile territorial seas but within the 200 mile zones of coastal States (see tables 1 and 2 ). These catches represent 83 per cent of the total $t$ ish catch taken from the core area in 1974 and approximately 100 per cent of that from areas influenced by extended jurisdiction. For this reason $I$ have 1 imited detailed discussion of the resources affected by extending jurisdiction to the highly migratory species.

\subsubsection{Tuna resources exploited in surface fisheries}

Within the area of the central and western Pacific bounded by the 20 degree parallels, surface fisheries for tuna rely predominant $1 y$ on catches of skipjack (Katsuwonus pelamis), which normally account for more than 90 per cent of the landings, and, to a lesser extent, juvenile yellowf in tuna (Thunnus albacares), which account for approximately 5-8 per cent. The more temperate regions of the western Pacific support substantial surface fisheries for frigate tuna (Auxis thazard), bluefin tuna (Thunnus thynnus to the north and Thunnus maccoyii to the south) and albacore (Thunnus alalunga), but fisheries for these species are not of major significance in the tropical central and western Pacific at this time.

The skipjack is a truly migratory species. Recent tag and recapture information has proven extensive migrations for individual fish; large numbers of skipjack have been tagged off the west coast 
of central America, twelve of which have been recaptured near Hawaii (IATTC 1976); one skipjack released near Japan was recaptured in Hawailan waters (Shomura, R.S. 1977, personal communication); skipjack tagged in the inshore waters of Papua New Guinea have been recaptured as far north as Palau and as far south as the central Solomon Islands (Department of Primary Industry, Papua New Guinea, unpublished data).

Although biochemical genetics information suggests that the skipjack resources of the Pacific can be divided into at least two (Fujino 1972), and possibly as many as five (Sharp 1976), subpopulations the ranges of these subpopulations overlap and vary in both time and space (Anon 1976b). The impact of these variations on the distribution of the skipjack stocks can be seen in the great seasonal and year-to-year fluctuations which occur in total catch and catch per unit of effort in the established fisheries in the western Pacific. Consider firstly the fluctuations which occur in locally-based fisheries in Papua New Guinea and the Solomon Islands, which rely almost entirely on skipjack caught within 30 miles of the coast of both countries. Summaries of total catch and catch per unit effort by the skipjack fleets for both countries are given in tables 3 and 4 . The great fluctuations in "apparent abundance" shown in these figures, as indexed by the catch per unit of effort or total catch, indicate the risks involved in expanding fleet sizes to take optimum catches in years of high skipjack abundance. The prospect of comparatively poor catches in the very next or subsequent years makes investment in very large fleets or processing bases an uncertain undertaking. Given that the fluctuations in catch per unit effort do not linearly represent changes in skipjack abundance in either of these fisheries (Anon 1976b) the differences in "absolute abundances" of skipjack between years are further emphasized.

When the great variability in the area fished and the distribution of the catches by the Japanese distant water fleets are also considered, the problem of defining skipjack resource distribution for the deployment of optimum fishing effort over the entire region is further compounded. This variation in distribution is shown in the atlases of the skipjack catches by month produced by the Tohoku Regional Fisheries Research Laboratory, (Tohoku Regional Fisheries Research Laboratory 1974, Tanaka undated (a), Tanaka undated (b)) and its implications have been previously discussed (Kearney 1976a).

Considering the great natural fluctuations which occur in skipjack abundance, along with the limitations of a minimum average catch rate required to support a viable industry, one can only endorse the claim that for long-range skipjack fleets of any nation to operate economically on a year-round basis, access to fishing areas within the exclusive economic zones of many countries will be required. It is also certain that the absolute catches by long-range vessels and the percentage of the total skipjack harvest taken from within the exclusive economic zone of individual countries will fluctuate markedly from year to year. Hence the necessity for at least a regional, and possibly an ocean-wide or even global approach to the management of this, the tuna species of highest economic significance. Additionally, a great deal more research is required before the expanded utilization and rational management of skipjack resources can be approached with any confidence. 


\subsubsection{The long-line caught tunas and billfish}

The total 1974 long-line catch of tunas (predominantly yellowfin tuna, bigeye tuna and albacore) and billfish from FAO statistical area 71 was approximately 100,000 tonnes (see table 1) valued at more than $\$ U S 70,000,000$ as fresh fish. As most of the long-line catch is taken by vessels from non-member countries of the United Nations more recent accurate data are not generally available. However from verbal reports from processers within the region there is little doubt that total production from the long-line fishery in the tropical Pacific declined dramatically in 1975 and early 1976, with some improvement in fishing in late 1976 and early 1977. All of the species of commercial significance to the long-line fishery are classified as highly migratory in the RSNT (1976) (table 5) and all migrate extensively throughout the Pacific regardless of international boundaries. In addition, the fleets which exploit these species are extremely mobile and cover huge areas, responding to changes in the species sought and to seasonal fluctuations in the distribution and availability, or relative abundance, of $\mathrm{fish}$. Furthermore, whole sections of the fleet shift from one fishing ground, or even one ocean, to another as the economics of the industry change with fluctuations in the comparative prices of the numerous species. Market price fluctuations have in recent years greatly influenced the distribution of the long-line fleet throughout the central and western Pacific in two major ways:

(a) The price of albacore on the Japanese market increased from less than \$US900 per tonne in February 1973 to more than $\$ U S 1,200$ in February 1974 before fluctuating widely, but finally dropping to less than \$US700 per tonne by the middle of 1975 (see figure 4). By October 1976 the albacore price had risen to more than \$US1,600 per tonne. These fluctuations caused opportunistic redirection of fishing effort from the yellowfin to albacore fisheries and vice-versa.

(b) The lucrative Japanese sashimi market has expanded and also absorbs an increasing amount of Korean-caught tuna. This has resulted in a shift of Japanese and Korean long-line fishing effort from the equatorial Pacific into the more southerly fishing grounds around southern Australia and New Zealand in search of southern bluefin tuna.

When the catches of tunas and billfish from all of the areas of the westem Pacific covered by this highly mobile long-line fleet in 1974 (FAO statistical areas 61,71 , and 81 , see figure 2) are combined they exceed 330,000 tonnes (table 1) with a fresh fish value of well over $\$$ US $200,000,000$. Practically all of this long-line-caught $f$ ish was taken from waters which are outside the present territorial seas (12 mile) of Pacific coastal States but most (and this applies particularly to statistical area 71 ) was captured in waters which will come under the jurisdiction of coastal States with the declaration of 200 mile zones of extended jurisdiction; hence the future management of these resources is in urgent need of review on a regional basis.

\subsubsection{Marine mammals}

\subsubsection{Whales}

Whales are also highly migratory and while there is currently no fishery for these huge mammals in the tropical central 
and western Pacific they do represent a resource of some potential to the region. In the nineteenth century whaling was the major industry of the region, and Lever (1964) wrote that "Few groups of islands in Polynesia went unvisited by the Nantucket and New Bedford whalers, who reached their heyday in 1846 with no less than 730 vessels engaged in this trade and taking $\mathrm{fl}, 400,000$ worth of whale products in that one year alone". Lever's estimation of the areas of maximum whale captures is given in figure 5. Although the stocks of right, humpback and sperm whales are all greatly reduced from the levels of the early nineteenth century (A1len 1975), coastal States of the tropical Pacific may be able to derive some benefit, perhaps indirectly, from the harvesting of these or other whale species in future years, particularly if preferential rights can be negotiated on the basis that the breeding grounds of several species are in tropical regions.

\subsubsection{Dolphins}

Dolphins are not commercially harvested from the tropical central and western Pacific and there are no such large catches of dolphins by tuna purse-seine vessels fishing schools of tuna associated with dolphins as occur in the eastern Pactfic. Hence extended jurisdiction is unlikely to have detectable lmpact on the management of dolphin resources in the foreseeable future.

\subsubsection{Dugong}

There are limited resources of dugong (Dugong dugong) in some Pacific Islands, particularly in the western areas, and this species is highly prized as food by most Island people. However, the total resource is limited and furthermore the species is coastal in distribution. While it may undergo migrations along coastlines, it cannot strictly be regarded as highly migratory. Conservation and management measures which may be required in the immediate future should remain national rather than regional problems.

\subsubsection{Marine turtles}

Marine turtles occur throughout the central and western tropical Pacific and are 1mportant both culturally and in the diet of coastal peoples of the region. Five species (green turtle, Chelonia mydas; hawksbill turtle, Eretmochelys imbricata; Pacific Ridley turtle, Lepidochelys sp.; loggerhead turtle, Caretta caretta; and leatherback turtle, Dermochelys coriacea) occur in the region but insufficient data are available to estimate the relative importance of each to local custom or commerce. However, the green and hawksbill turtles probably dominate the harvest from the area (Hirth 1971). Catch figures are extremely scarce from the whole western tropical Pacific; the only figures compiled on a regional basis are those by FAO (see FAO 1975), which merely indicate catches from statistical area 71 in 1974 as 4 , when measured to the nearest tonne. This certainly underestimates the quantity taken and equally certainly does not reflect the importance Island peoples attach to their turtle resources.

Fishing by nationals of coastal States within the respective territorial seas probably accounts for the greater part of the present yield of turtle meat and almost all the turtle eggs taken within the region. The impact of extended jurisdiction on turtle management will 
largely depend on cooperation by all coastal States in the area in formulating their national fisheries policies to maintain optimum production from the remaining turtle breeding areas. For the purposes of controlling the harvesting of turtles by nationals of other than coastal States, it would appear appropriate to regard turtles as anadromous species, for breeding on the land of a coastal State is surely equivalent to breeding in a river of a coastal State, and in this regard Article 55.1 of Part II RSNT (1976) is relevant: "States in whose rivers anadromous stocks originate shall have the primary interest in and responsibility for such stocks". If such an approach is taken to the management of turtle resources then national rather than regional policies will dominate conservation measures.

\section{Management of Iiving Oceanic Resources and the Need for a Regional Approach}

4.1 The objectives of management

Many definitions of the objectives for the management of living aquatic resources are available in the literature. The three major topics outlined by Alverson and Paulik (1973) and given below (4.1.1 - 4.1.3), are representative of the accepted principles:

\subsubsection{Maintenance of the resources}

Included under this topic are all objectives necessary for the conservation of the resources. The definition of conservation set out in Article 2 of the Convention on Fishing and Conservation of the Living Resources of the High Seas from the 1958 Geneva Convention on the Law of the Sea (Anon 1958) is relevant. It defines conservation of the living resources of the high seas as "the aggregate of the measures rendering possible the optimum sustainable yield from those resources so as to secure a maximum supply of food and other marine products". The emphasis in this definition is on exploitation of marine resources (Joseph and Greenough 1977) and it is in general agreement with the need to maintain any resource at a level capable of supporting the maximum sustainable yield. Although there is considerable disagreement between scientists on whether the acceptable management goal is maximum sustainable yield or maximum economic yield, the need for continuation of the resource at exploitable levels goes undisputed.

Since fish stocks are a renewable resource only if properly managed, the need to conserve the species is implicit in acceptance of the need to maximize/optimize returns. As the major species of interest here are highly migratory, they are potentially vulnerable to over-exploitation in any area of their distribution and conservation must therefore be considered in the context of their total distribution; that is, conservation measures must be established on a regional basis.

\subsubsection{Maximization of socio-economic beneits}

The need to ensure that the fisheries of the tropical western and central Pacific remain economically viable is, in terms of management objectives, second only to the need to ensure perpetuation of the resources themselves. Furthermore, practically all socio-economic 
objectives are dependent up on the maintenance of resources at productive levels. Over-capitalization of a fishery can have an adverse impact on individual boats and fishermen (i.e. on the whole catching sector of the industry) financially equal to a reduction in the total resource base due to over-fishing. Fluctuations in monetary returns per unit of fishing effort therefore need to be monitored, together with catch and effort information and, if necessary, management procedures, which might include limited entry over perhaps the entire distribution of the resource, need to be considered.

To maintain satisfactory returns from the total fisheries resources of the region numerous other socio-economic objectives must be taken into account. Moreover, it is certain that some of the socio-economic objectives favoured by some countries of the region will not be equally pursued by others. For example, some countries will view increased fishing activities primarily as a means to increase local production to meet the protein requirements of their people, while others may consider increasing employment opportunities for their residents as the primary objective. In still other countries the primary concern may be the development of export fisheries as foreign exchange earners, or the displacement of imported fisheries products which adversely affect foreign trade balances. Different countries may adopt different objectives, and different combinations of objectives may dictate policies which differ between countries of the region. In addition, individual policies may themselves vary with time. Most commonly, major differences in socioeconomic objectives between countries are the result of great differences in the state of economic development of the countries themselves. In this regard the countries in the core area previously described (figure 1) are unifled in being developing coastal States and their needs are numerous but common to all.

\subsubsection{National and international political objectives}

Although political considerations will obviously play a major role in the formulation of a set of regional fisheries management objectives, it is not within the scope of this technical paper to consider political implications except by noting their existence and potential importance. National politics will undoubtedly influence the goals set by member countries.

At an international level one of the main objectives could be to create a more harmonious relationship among the user groups of the ocean resources (Alverson 1973). Again, the common interests of the countries of the core area and their power if a common policy is adopted (sections 4.2 .8 and 4.2.9) should be noted.

\subsection{The need for a regional fisheries body}

In section 3 the domination of the known fisheries resources of the tropical central and western Pacific by highly migratory species has been clearly shown. The significance of these resources not only to total fisheries production but also to the economy of the region as a whole has also been indicated. It is in the interests of all countries in whose waters highly migratory resources occur to ensure that the stocks are not subjected to excessive fishing pressure that might threaten their existence or lead to over-capitalization of the industries to the point where they 
are no longer economically viable. Furthermore, given the inadequacy of world-wide fisheries resources to meet increasing world demand, particularly in developing countries, it is essential that the yield of $f$ ish from all oceans be maintained at levels approximating the maximum sustainable yield. The central and western Pacific cannot be excepted.

As rational management cannot be achieved without access to adequate scientific and statistical data, the maintenance of a suitable research and management body (or bodies) is implicit in a decision to manage a fisheries resource. For the reasons given below this task could most easily be carried out by a single regional fisheries body for the western and central tropical Pacific.

\subsubsection{The need for regional fishery statistics}

Analyses of the fisheries of the central and western tropical Pacific are presently severely hampered by the lack of statistics compiled specifically for this region.

As the major resources are highly migratory, fisheries policies will need to take account of all fisheries on the common resource. This will not be possible until accurate statistics are produced, presumably by a regional agency.

\subsubsection{The highly migratory nature of the resources}

Al1 of the major resources are highly migratory and individuals or whole populations freely travel from the waters of one coastal State to those of others. Declaration of new national or international boundaries will have no impact on the distribution of the fish themselves (see sections $3.1 .1,3.2 .1$ and 3.2 .2 ).

\subsubsection{The mobility of the fleets harvesting the resources}

The fleets which harvest these high1y migratory resources are themselves extremely mobile. More than 83 per cent of the total fish catch taken from the core area (figure 1) in 1974 was taken by international fleets which fish in this region for only part of each year. (see sections 3.2 .1 and 3.2.2).

\subsubsection{The variable distribution of the resources}

The areas of occurrence of fishable concentrations of all the major species will vary substantially in both time and space. This variability makes it impossible to predict which area of the total region will yield the greatest catches at any given period of time (see sections 3.2 .1 and 3.2.2).

\subsubsection{The variable vulnerability of the species concerned}

The comparative vulnerability and availability of some species vary greatly both in time and over the area of distribution of the resource. For example, the skipjack season off New Zealand is very limited in time and yet when skipjack do occur there they are readily available to all fishing gear, occurring close to the coast. In the New Zealand area they are very vulnerable to purse-seine gear and this high vulnerability is characteristic of very limited areas of the western Pacific, where it introduces an additional problem in formulating management strategies. Even though skipjack are regional 
in occurrence the distribution is not unfform and in areas where purseseining is effective, the percentage of the total biomass which is harvested is often greater. Therefore the differences between the various fishing efforts in a variety of situations need to be considered in the management of the total resource.

4.2.6 The dependence of the resources of the region on common spawning or nursery grounds

Skipjack spawning in the Pacific Ocean concentrate in the equatorial waters of the western region of this ocean. However, although spawning is most intensely carried out in the tropics, the growth rates of skipjack are much higher in more temperate regions where the fish are first recruited into the surface fisheries (Kearney 1976b). While this difference in growth rate may in fact be associated with the occurrence of separate populations of skipjack (Kearney 1975a), both major postulated subpopulations occur and spawn within the core area described. However, the fact that the temperate regions of the western Pactfic serve as nursery grounds for at least some of the skipjack spawned in more tropical areas must not be overlooked. That is, intrafishery interactions over the entire distribution of the resource must be considered.

Most highly migratory tuna species exhibit differential distribution with size, and consideration of the regional implications of this phenomenon cannot be restricted to skipjack.

\subsubsection{Interaction between surface and long-line fisheries}

In addition to the more obvious problems of managing or conserving the stocks of individual species, the interaction between surface and long-line fisheries must be considered. The two different fisheries in effect operate in parallel on the stocks of some species at different stages of their life cycles. Whereas surface tuna fisheries almost always exploit juveniles, behavioural changes of the $f$ ish with increasing maturity result in mostly adults being caught by the long-1iners. Recent catch figures show that this interaction is most apparent for yellowf in tuna and albacore. Preliminary estimates of catches of juvenile yellowfin tuna from FAO statistical area 71 indicate that 7,250 tonnes were taken by surface fishing gear in 1974 (Kearney 1977). This weight of yellowf in tuna would have comprised approximately the same number of individual yellowfin as were captured by the long-line fishery in the peak years of 1972 and 1973 when catches were of the order of 56,000 tonnes (Kearney 1977). Large quantities of albacore are also taken by both surface gear (as juveniles) and long-line (as adults) in the western Pacific and as the catches by surface gear are restricted to the higher latitudes, the need to make coordinated assessments of the albacore resource, considering the impact of fishing pressure at all stages of its life cycle and over its entire range of distribution, must be stressed.

Bigeye tuna are also taken as adults by long-lines and as fuveniles by surface gear, but differ from albacore in that the juveniles are taken in equatorial areas, and adults from the same, or more temperate, areas. Again the need for a comprehensive approach to stock assessment is accentuated.

Bluefin tuna, Thunnus thynnus to the north and Thunnus maccoyii to the south, are taken as juveniles by surface fishing gear and as 
adults by long-lines in the western Pacific but outside the core area of figure 1. Although bluefin tuna could possibly be excluded from a list of the resources of the central and western Pacific, the fleets which fish for them are highly mobile and their catches of ten include substantial quantities of other tunas and billfish which migrate through this region. Furthermore, the vessels involved in the bluefin fishery may move to other longline fisheries. The fisheries for bluefin tunas therefore warrant careful consideration when regional fisheries policies are determined.

\subsubsection{Common interest of developing countries of the region}

All of the developing countries of the central and western tropical Pacific want to increase their harvest from the oceans surrounding them. None of these countries have large long-range fleets which fish throughout the region and there is a uniform desire to share in the benefits derived from harvesting the substantial regional fisheries resources. This common interest would best be served by the establishment of a common, regional body whose role it would be to analyse the possibilities for active participation and increased benefits by coastal States (the developing countries) and to present a comon front for negotiations with the more developed fishing nations.

\subsubsection{Added power of a common interest block}

As indicated in figure 3 the declaration of 200 mile zones of extended jurisdiction by all of the Island countries and territories of the equatorial Pacific will effectively bring all of the western tropical Pacific under the control of coastal states. If a common policy on resource assessment and management is adopted then the power of this common block to ensure sound management of fisheries resources is enhanced many-fold. Indeed the resources of this area cannot be adequately managed if a common policy is not adopted.

\subsubsection{Prevention of duplication of research effort}

A regional approach to the study of highly migratory species will not only enable the species to be monitored over their range of distribution but will also obviate the need for each of the countries of the region to undertake substantial individual research effort. As the species are highly migratory each country would require sizeable ocean-going vessels and a large research staff to cover even that fraction of the species habitat which occurs within its own zone of extended jurisdiction. The costs involved in maintaining a single regional research facility would be much less, and regional cooperation would ensure that the research effort covered all areas of occurrence of the common resources within the region.

\subsubsection{Minimizing surveillance effort}

Adoption of a regional approach to surveillance will (a) greatly reduce the total effort needed by reducing the total length of nationa 1 boundaries to be policed, (b) make 11 legal fishing in the central areas of the region extremely hazardous, (c) facilitate enforcement of management procedures, and (d) avoid duplication of surveillance facilities. A detailed discussion of this topic is given in section 5.1 .6 . 


\subsubsection{The need to ensure access to the fishing grounds}

Universal acceptance of 200 mile zones of extended jurisdiction will bring fishing activities in almost all of the central and western tropical Pacific under the management of a coastal State (figure 3). When this occurs one of the most immediate problems facing all countries with distant water fishing fleets will be that of resource access. Having access to a resource or area is normally considered as being allowed to fish on a particular fishing ground or in the waters of a specifled coastal State. However in the central and western tropical Pacific access in its more classical meaning, that is "a way or means of approach" (Shorter Oxford English Dictionary, 1947), is in itself a potential problem. Declaration of 200 mile zones of extended jurisdiction in this area will mean that several coastal States and their exclusive economic zones will be isolated from the high seas by the juridical zones of other coastal States (see figure 3). Access by the international fleets, which currently dominate fisheries production from the area, to the juridical zone of practically every coastal State in the region will necessitate traversing the zone(s) of one or more additional States.

Articles 18 and 20 of Part II RSNT (1976) refer to this problem of innocent passage within the territorial sea of coastal States, and innocent passage through straits used for intemational navigation is further covered in Chapter II, particularly Article 43. However, the problem is unusually complicated in the context of the passage of tuna fishing vessels which utilize surface fishing gear through zones of extended jurisdiction. Live-bait and pole, and purse-seine vessels account for all the catches of tuna in the surface fisheries of the western Pacific. Both types of vessel normally fish by searching the ocean at cruising speed and fishing only when surface tuna schools are encountered. Thus their gear can be fully operational in seconds and in the case of live-bait and pole vessels, fishing can cease just as quickly. It is therefore extremely difficult to differentiate between periods of searching for fish and innocent travelling.

If the individual coastal States of the core area (figure 1) adopt independent policies on the licensing of foreign vessels, then the problem of access to the waters of coastal States, particularly the more southern ones, becomes extreme and the difficulties and costs of enforcing "innocent passage" could well cause major international problems in the region. A regional approach to licensing (see section 5.1.5) and to surveillance (section 5.1.6) appears to be the most likely way to ensure access to, and optimum utilization of, the regional resources.

4.3 Consideration of the principles outlined in the UN Law of the Sea texts.

The need for a regional fisheries body in the central and western tropical Pacific where the major resources are highly migratory is endorsed by Article 53, Part II RSNT (1976) which states "The coastal State and other States whose nationals fish in the region for the highly migratory species listed in the annex [table 5] shall cooperate directly or through appropriate international organizations with a view to ensuring conservation and promoting the objective of optimum utilization of such species throughout the region, both within and beyond the exclusive economic zone. In regions where no appropriate international organization exists, the coastal State and other States whose nationals harvest these species in the region shall cooperate to establish such an organization and participate in its work". 


\section{The Role of a Regional Fisheries Body}

\subsection{The possible tasks of a regional fisheries body}

Earlier in this paper I have pointed out that problems associated with the assessment and management of fisheries for highly migratory species and certain other offshore living resources will, at least in the short-term, dominate the activities of a regional fisheries body. I will therefore restrict further discussion of the role of this body to activities involving oceanic fisheries and the species exploited in such fisheries. I have assumed that regional interests in inshore fisheries will continue to be served by the South Pacific Commission whose ongoing fisheries projects are structured primarily for this purpose.

Until the Governmerts of the region have agreed upon the objectives of a fisheries body, it is not possible to define the actual role it will play in such matters as resource assessment, management or surveillance. clearly there are many possibilities. Some objectives, such as preliminary resource assessment, may be accomplished in the short-term by a relatively small secretariat while others, such as resource management and surveillance, imply ongoing activity by a more substantial organization. Six major areas of concern have been listed in 5.1.1 to 5.1.6 and a three-phase approach to the pursuit of these objectives is outlined in 5.2. A multiphasic approach to the development of a regional fisheries agency, or commission, is further considered in section 6 .

\subsubsection{Resource assessment}

The first step in the management of any fisheries resource is to obtain an assessment of the magnitude, distribution and dynamics of the resource. The current state of knowledge of these essential topics for the central and western tropical Pacific is inadequate for most of the species of primary and immediate concern, i.e. the highly migratory tunas and billfishes, and data on the species which may be harvested from open ocean seamounts simply do not exist. In most of the countries and territories of the region facilities are not available to handle the collection of relevant data, even when such data are available, and detailed analysis for prediction modelling and stock assessment purposes is generally not possible. Therefore an essential task requiring immediate attention by the regional fisheries body will be assessment of the available resources. This assessment can only be achieved by utilizing the necessary scientific and technical information over the range of distribution of the species concerned.

\subsubsection{Fishing statistics}

Adequate statistics on a timely basis are a prerequisite

for all fishery assessment programmes. For different fisheries and areas the statistical requirements for adequate coverage will vary, but for these purposes adequate statistics would include:

(a) details of the catch, by species and size class, for each unit of area (probably either 1 degree or 5 degree squares) for every fishing day;

(b) detailed description of effort including declaration of vesse 1 size, fish carrying capacity, number of crew, gear type, units of gear used (e.g. size of nets or number of hooks). 
For the western and central tropical Pacific region the bulk of the tuna and billfish catch is currently taken by foreign vessels and basic catch and effort data are not available to the coastal states. In many cases even the total catch from the region is not known. It is therefore essential that a regional fisheries data collection and processing unit be established as an integral part of the regional fisheries body.

\subsubsection{Biology and behaviour of the important fish species}

Assessment of fishery resources will only be accurate if due account is taken of the biology and behaviour of the species being considered. The detailed requirements for biological information will vary slightly from species to species and between fisheries which utilize different gears but, in general, basic essential information will include:

(a) knowledge of the growth rate of each species and variations in growth which occur throughout the total area of distribution of the species;

(b) delimitation of the spawning grounds of each species and the time and duration of spawning;

(c) determination of the migratory patterns of each species and the degree of immigration to and emigration from the major fishing grounds;

(d) knowledge of the behaviour of each species, particularly as variation in behaviour influences vulnerability to different types of fishing gear and therefore leads to discrepancies between estimates of catchability and total abundance of each species;

(e) description of the food chains which support each species and estimation of species interaction in (i) predator-prey relationships and (ii) direct competition for food. This would carry over to an analysis of the interaction between fisheries as outlined under section 4.2.7.

\subsubsection{Stock description}

In recent years the skipjack resources of the Pacific Ocean have been divided into at least two and possibly as many as five subpopulations (Anon 1976b) on the basis of biochemical genetics. It is more than possible that subpopulations of the other tuna and billfish species also occur. In order to determine the impact of fishing on the resources as a whole the population structure must be understood. A regional research effort must be undertaken to discover this population structure and the results used together with catch and effort data, and migration and other biological information, to monitor the dynamics of the various stocks or populations.

\subsubsection{Environmental description}

The importance of equating the apparent abundance of highly migratory species with the changes in their physical environment has only been fully realized in the last few years. In order to monitor and predict the area of optimum occurrence and vulnerability 
of the fisheries resources of the region it will be necessary to collate and analyse the considerable oceanographic information already available and to direct the collection of additional data from commercial fishing vessels, ships of opportunity, or research vessels operating throughout the area. The responsibility for coordinating this work should be accepted by the regional fisheries body.

\subsubsection{Economic appraisal of the fisheries}

While a regional fisheries body should not be so deeply involved in economic fisheries policy that it would dictate investment strategies to the participating parties, it is essential that such an organization be cognizant of the nature of the profits and losses encountered in the various sections of the industry and bear these in mind when advising governments on the impact of management options. This is particularly pressing for the central and western Pacific region where many of the developing countries do not at this time have the expertise to accurately evaluate their fisheries management or development alternatives.

The economic advice required from the regional body would vary, but would include assessment of fluctuations in the operating costs for various fisheries, including vesse 1 and gear costs, fuel, labour, bait etc. and the fluctuations in returns from fishing as catches and fish prices fluctuate, the overall goal being to facilitate regional management within the framework of maintaining maximum sustainable yield or maximum economic yield as outlined in sections 4.1.1 and 4.1.2.

\subsubsection{Management of fisheries resources}

Since the middle 1960 s it has been widely accepted that the world's resources of the large tuna species are being exploited at, or near, the levels which would produce the maximum sustainable yield. However, the world demand for tuna continues to approximately double every ten years (Chapman 1963, Kearney 1976c). Obviously finite tuna resources cannot continue to meet this increased demand. The possible consequences are outlined by Saila and Norton (1974) "It seems evident that the extensive migrations of tunas, the increased mobility of the tuna fishing fleets, and the rapid expansion of capacity in these fleets combine to present serious and immediate global management problems. Unless rational management agreements are reached soon, competition for the international tuna markets will intensify competition for the tuna resources. The result will be excess fishing effort and significant losses to the world community because of declining yields and unnecessarily high catching costs". This concern over increasing effort for limited resources of highly migratory species is not restricted to tunas, and Joseph (1973) points out "Similarly, combined catches of billfishes have not increased in recent years though fishing effort for them has increased, and for some billfish species catches have declined".

The problem of management of highly migratory resources is common to the world's oceans and while this problem is universally recognized the urgency of the problem is not widely appreciated: "Many fisheries scientists and administrators do not seem to realize even now that the days are gone in which years can be taken in studying and taking action on a particular fisheries problem, for the 
time is gone in which problems can take years to develop. With modern vessels, gear, and techniques, it is increasingly easy to create a new problem overnight, and problems of fisheries management must be dealt with speedily." (Sullivan 1971).

The fisheries management requirements of the tropical central and western Pacific are increasing with the recent expansion in catches from the area (see section 3), and a regional approach must be made to satisfying these requirements (sections 4.1 and 4.2). The duties of any regional fisheries body should therefore include at least the formulation of management strategies.

The traditional objectives of management: the conservation of species; the maintenance of stocks at levels which support optimum yields; the maintenance of maximum production from the region; the facilitation of economic stability of the industries; and assurance of access to the fisheries by developing countries, have already been discussed (section 4.1), but with the universal acceptance of extended jurisdiction, traditional management goals will need to be revised to accommodate the increased rights of coastal states (section 2.1.1) and to consider resource allocation and the redistribution of benefits derived from the resources.

\subsubsection{Determination of resource ownership and/or resource allocation}

Along with the maintenance of stocks at levels which will produce maximum sustainable yields, the determination of ownership of resources and the allocation of these resources amongst the interested parties are the most pressing problems facing fisheries management today; they must be considered as an integral part of any management system. While the universal acceptance of extended jurisdiction to 200 miles will largely solve the problem of ownership for the more sedentary coastal species, it by no means clarifies ownership of highly migratory resources. Even though access to that part of the total stocks which occurs within 200 miles of a coastal State at any one point in time may be determined by the coastal State, the highly migratory nature of tuna and billfish resources will mean that this component of the total resource in any one 200 mile zone will be constant1y changing. A portion of the resource under the control of one coastal state for a time will, due to its migratory behaviour, come under the jurisdiction of another State or States within a very short period. Furthermore, the gross seasonal and annual variability in the abundance and catchability of these resources will make it extremely difficult to determine the fraction of the total resource of even one species which might occur within a zone of jurisdiction of one coastal State, and the length of time that the fish comprising that fraction can be anticipated to remain. The problem is further complicated by the fact that the spawning or nursery grounds often occur thousands of miles from the main fishing grounds. It is possible that in resource allocation special consideration might be required for countries in whose waters spawning or early growth take place because it is vital to ensure that the breeding and nursery grounds are protected and recruitment to other fisheries is guaranteed. In addition, Article 51 Part II RSNT (1976) provides for special consideration to be given to developing countries within the area of distribution of the resource and to the minimization of economic dislocation in States whose nationals have habitually fished the area. 
Alternatives available for resource allocation in the eastern Pacific tuna fishery have been discussed in great detail by Joseph and Greenough (1977) and many of these alternatives are relevant to the western and central Pacific, bearing in mind the differences in these two areas. Joseph and Greenough also considered a number of possible management options and concluded that systems involving control by individual coastal States within their own 200 mile juridical zones had specific shortcomings, depending to some extent on the management approach under consideration, but that all approaches would be plagued by a failure to adequately resolve the catch allocation problem. They noted that resource adjacent nations wishing to harvest tuna, say in quantities equivalent to the average amounts taken by the international fleet from their coastal waters, could not possibly do so year after year if they were restricted to fishing only in their own juridical zones because of the highly variable migratory behaviour of tuna. They considered four allocation possibilities as follows:

(a) Open-access management with participant fees.

(i) Partial catch allocation and preferential allocation to resource adjacent nations (RAN).

(ii) Open-access fishing and international licensing.

(b) Regional coalitions.

(i) RAN coalitions with exclusion of non-RANs.

(ii) RAN coalttion with licensing of non-RANs.

(iii) Coalitions of RANs and non-RANs with allocations.

(iv) Coalitions of RANs and non-RANs without allocation.

(c) Total allocation of the resource.

(d) Resource allocation by competitive bidding.

These options are also open to the central and western tropical Pacific but the selection of the most suitable system for this region must be preceded by a decision in favour of regional cooperation. For the reasons outlined in sections 4 and 5.1 .3 it is argued that the interests of the countries of this region will be best served by the adoption of a common policy on management, resource allocation and licensing and that the interests of the developing countries should have precedence in the management policies formulated. The core area depicted in figure 1 can be regarded as a single unit of area for management purposes due to (a) incorporation of most of this area into the $200 \mathrm{mile}$ zone of one or other of the developing countries of the region (figure 3) and (b) acceptance of the principles outlined in Article 53, Part II RSNT (1976) as discussed in section 4.3. A single management control could therefore effectively be exerted over the whole area. When adopting management strategies, countries of the core area must be cognizant of the need to consider management of the resources of each species over its entire area of distribution, or at least over the area of distribution of its subpopulations.

As it will be a primary task of a regional fisheries body to consider in detail the options available for management and resource allocation and to make recommendations accordingly, only the broad outlines of what is considered most likely to form the basis of such allocations are given in this paper. 
Given that the developing countries of the region do not have their own international fleets but that most countries do plan to further develop their coastal skipjack and tuna fishing activities, there may well be disparity between the courses of management most suited for fulfilling short- or long-term objectives. For the short term it is anticipated that a regional management body will work towards

(a) determining the maximum allowable catch of each species, or stock, which can be taken while maintaining maximum sustainable yields;

(b) ascertaining how much of the total resource can be legitimately claimed to occur in the economic zone of each country in an average year and estimating what part of this resource is captured from each zone;

(c) advising on the licensing of foreign fleets to take the surplus catch from all other areas under its jurisdiction, pursuant to the need to maximize the harvest of $f$ ish from the region (the nature of such licensing is considered in section 5.1.5) and to protect the exclusive fishing rights of coastal States.

The long-term objectives will change as the countries of the region develop their own international fleets and begin to compete between themselves and with foreign fleets for the resources which, as previously discussed, vary in their area of occurrence from season to season or year to year. In the long-term, management objectives will need to include

(a) continuous adjustment of resource allocations to developing countries as they increase their capacities to harvest resources which occur within their economic zone in an average year (see (b) above);

(b) redistribution of benefits derived from licensing according to the principles outlined in section 5.1.5.

The chances of realizing the objectives given above will, to a great extent, be dependent upon complete cooperation between all the coastal States of the region and on the successful surveillance and control of all vessels involved in the various fisheries.

5.1.5 Licensing of foreign vessels and the redistribution of revenue

In section 3 it has been shown that the total fish catch from the central and western tropical Pacific greatly exceeds that taken by the numerous coastal states (see tables 1 and 2). It has also been pointed out that the greater part of the catch taken by noncoastal States is taken within waters which will come under the jurisdiction of the coastal States of the region when $200 \mathrm{mile}$ zones of extended jurisdiction are universally accepted. The most obvious result of acceptance of 200 mile zones would therefore be control by the coastal States over the harvesting of substantial quantities of highly migratory species which are taken from waters presently recognized as international. Although the coastal States of this region do not at present have the fishing vessels to harvest all of the additional resource which will come under their control, there is 
provision in Article 51 Part II RSNT (1976) for coastal States to license vessels of other nationals to harvest the resources in excess of the capacity of the coastal State. Article 51.4(a) indicates that this licensing "in the case of developing coastal States, may consist of adequate compensation in the field of financing, equipment and technology relating to the fishing industry," and other forms of remuneration. It is therefore in keeping with the principles of the RSNT to assume that in the case of coastal States which license foreign vessels to harvest the excess of the allowable catch, determined by the coastal state (Article 50), in their exclusive economic zone, some financial or other remuneration could be derived from this licensing. As $i t$ is in the best interests of the coastal States of the central and western Pacific to maximize the benefits which may be forthcoming, alternative licensing policies should be given careful consideration before a licensing system is adopted. Some of the more commonly considered alternatives are as follows.

\subsubsection{Some alternatives for licensing}

(a) A separate license fee to fish within the exclusive economic zone of each coastal State

As I have pointed out in an earlier paper (Kearney 1976a), such a system would be impracticable and unprofitable because of the multiplicity of management and surveillance systems necessary to enforce payment by vessels to all countries in whose waters they have fished.

(b) A common license fee to enter a regional fishery

Acceptance of a common license fee and the resultant single administrative system is obviously more feasible than (a) above. However there are still many problems in the determination of the fee payable by each vessel. A flat rate per vessel would not be representative of the fishing effort. A fee per unit of carrying capacity or other unit of fishing power appears more realistic but even so over what time scale should fees be rated? Per month? Per year? Per fishing trip? Also, such a system may not take account of times of good or bad fishing when vessel owners are more, or less, able to meet substantial fees. Therefore it would not be the most suitable for either coastal states or other nationals.

(c) A license fee based on the catch taken from the region (catch tax)

Imposition of a catch tax or participation fee based on the amount of $f$ ish taken by nations or individual vessels would solve many of the problems raised in (a) and (b). However, such systems are by no means problem-free and the following guidelines warrant consideration:

(i) The fee must be uniform throughout the region.

(ii) The total number of vessels allowed to fish must be kept within that required to take the maximum/optimum catch possible while maintaining sustainable yields.

(iii) The absolute fee will need to be set for each fish species and/or gear type used to catch the fish, bearing in mind the dynamic nature of the economics of fishing 


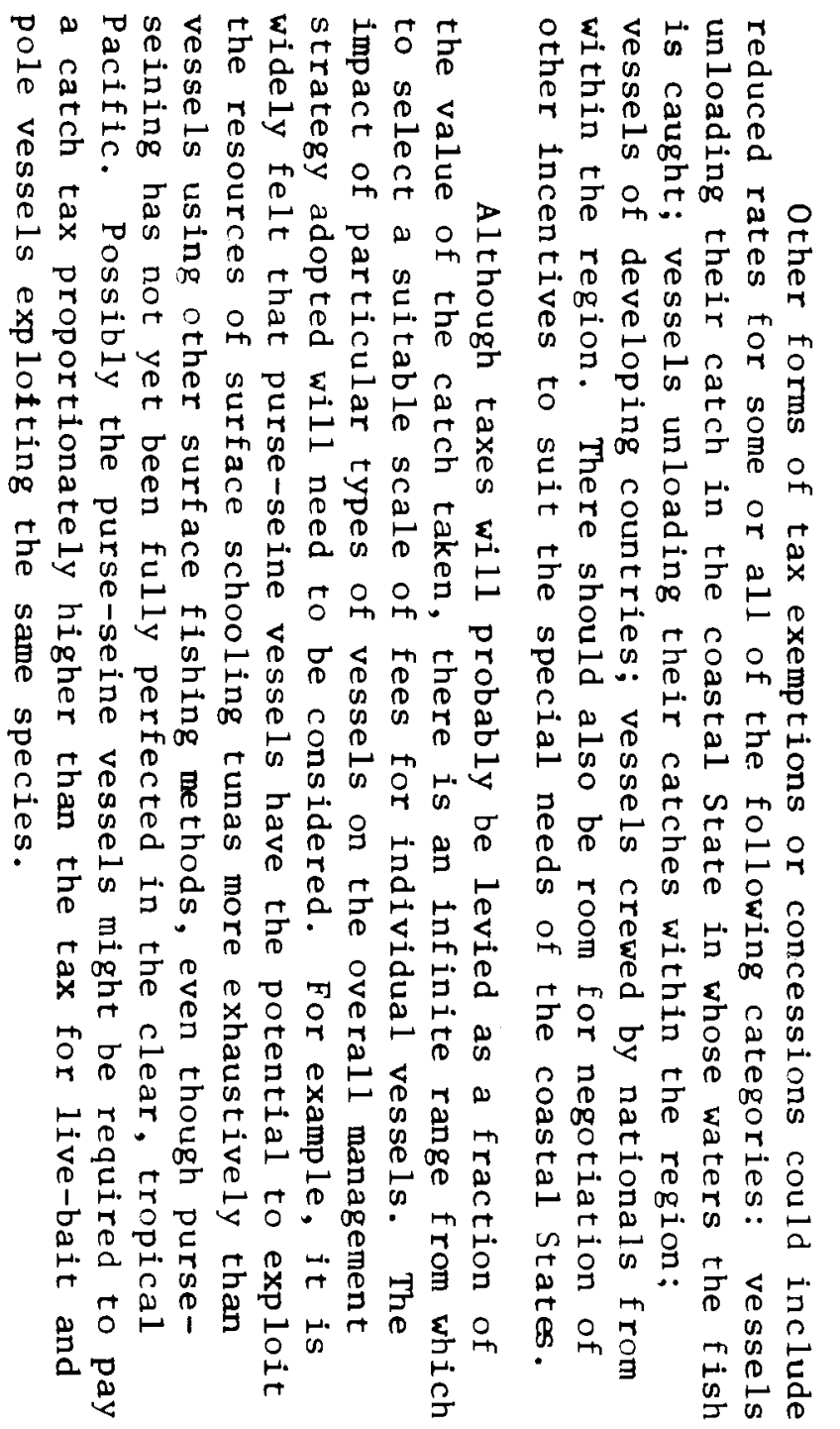

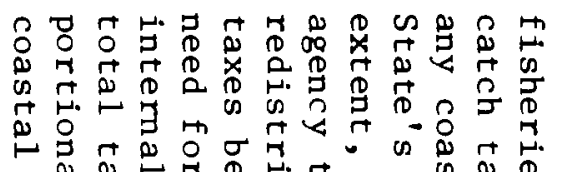

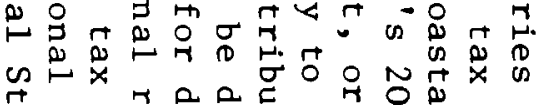

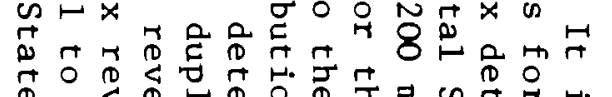

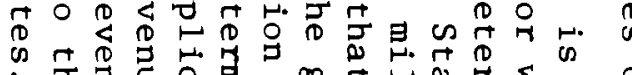

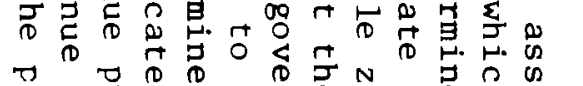

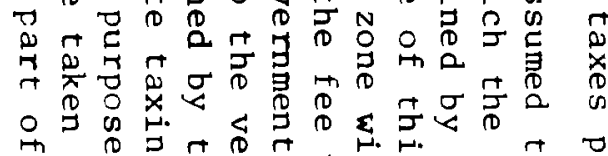
$\overrightarrow{0}$

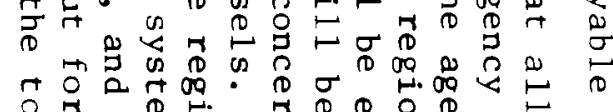

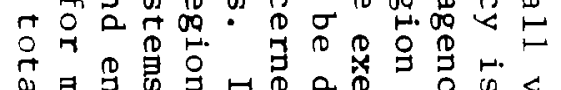

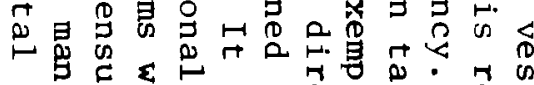

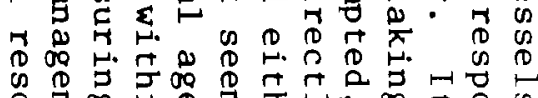

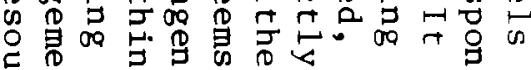

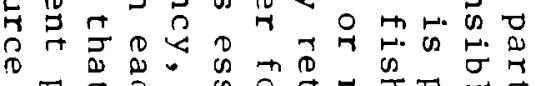

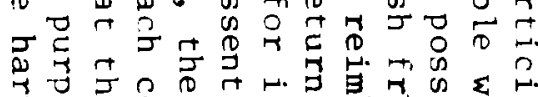

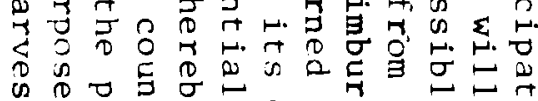

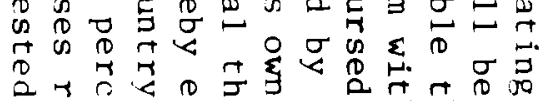

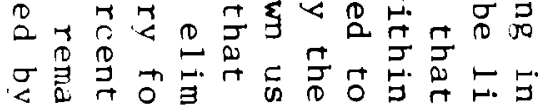
$<\underset{\exists}{x_{0}}$

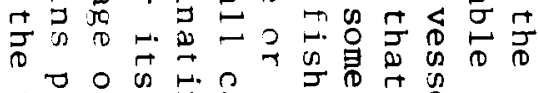

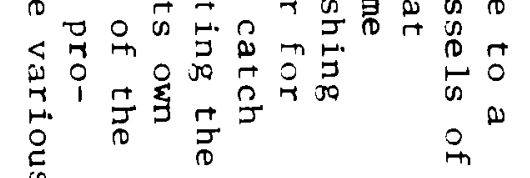

$u$

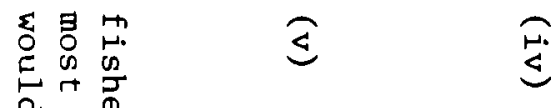

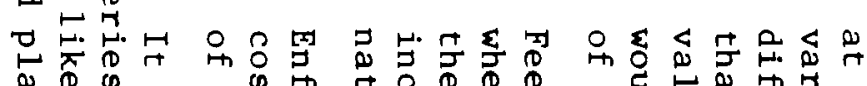

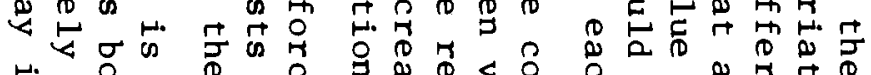

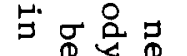

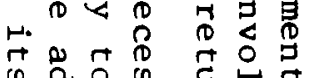

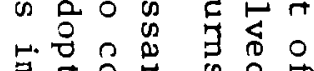

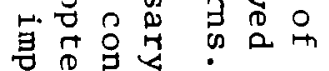

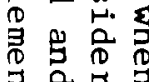
ta

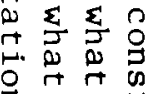

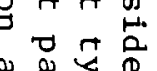

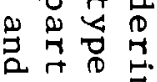
$\infty$ 我西

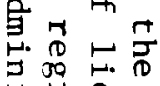
is.

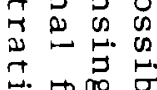
ث. 3

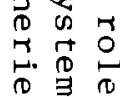
is

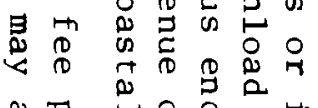

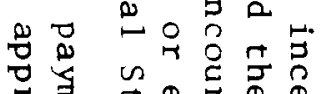

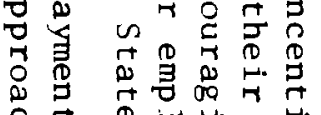

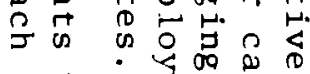

ㅌ․

舟吕

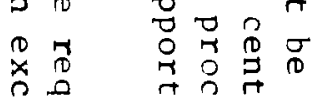

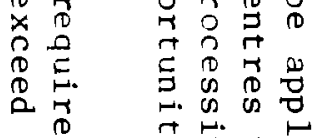

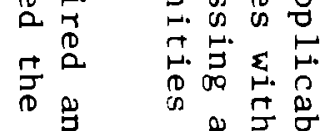

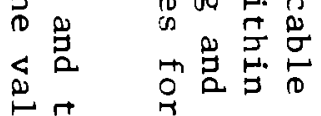

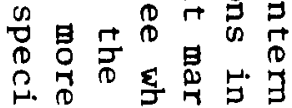
is 20 .

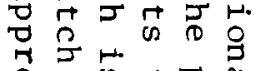

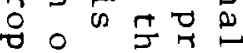

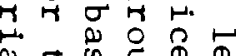

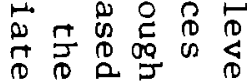
$\triangle 0$.

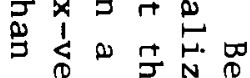

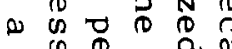

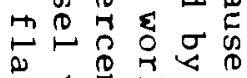

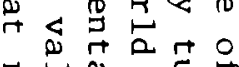

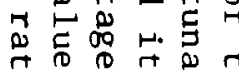

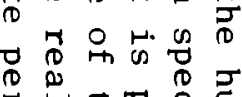

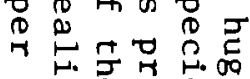

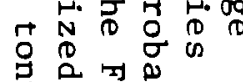

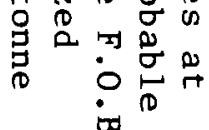

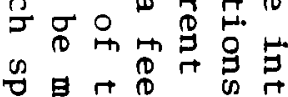


Current economics of the various types of fishing operations will need to be considered when a license fee system is derived; the present poor state of the long-line fishery may warrant special consideration being given to long-line vessels, at least in the short term.

Appreciating the flexibility required in drawing up a participator tax system it is still possible to give some indication of the ranges of catch tax which might on the one hand be acceptable to coastal States and on the other be tolerated by the fishing vesse1s. Indeed, precedents have already been set in other parts of the world and a western and central Pacific fishery agency should examine the relative success of these licensing systems.

Tuna fishing vessels from the United States of America have been paying fees of $\$ 30$ per ton carrying capacity of the vessel for fishing rights within the 200 mile zone of some South American countries. Joseph and Greenough (1977) point out that on the basts of 1976 tuna prices, a fee of $\$ 40$ per ton for yellowfin tuna and $\$ 30$ per ton for skipjack would be the maximum that vessels operating in the eastern Pacific surface tuna fishery could tolerate. These figures represent betweer 5 per cent and 7 per cent of the value of the yellowfin tuna and skipjack landed in United States ports in 1976. If a figure of 6 per cent was the average realized from licensing foreign vessels fishing in the core area of the central and western Pacific and it was assumed that all the tuna taken by foreign vessels in this area was from within 200 miles of a coastal State, then the revenue realized by licensing foreign vessels in 1974 would have been approximately \$US12,700,000. \$US15,800,000 would have been realized from the licensing of all vessels.

On the other hand, the United States of America has proposed a licensing system for foreign nations harvesting the declared excess of all fish species within 200 miles of the U.S.A. The fees payable by each foreign nation are $\$$ US 1.00 per gross registered ton of the vessels, not to exceed $\$$ US5,000 per vesse1, plus 3.5 per cent of the total dockside value of the catch allocated to that nation (Anon 1977a). This system puts the onus on the governments of foreign nations to ensure that licensing fees are met. Further, it assumes that the allowable catch of each species has been determined. A similar scale of licensing in the central and western Pacific under the conditions already described would realize approximately $\$$ US 7,500,000 per year from foreign vesse1s and $\$ U S 9,200,000$ from all vessels if catch rates continued at the 1974 levels. Japan has challenged the abovementioned USA catch tax of 3.5 per cent and has asked for a reduction to a leve 1 of 1.5 per cent on the grounds that the profit margin from this distant-water fishery is only 5 per cent (Anon 1977b).

\subsubsection{Redistribution of fee or catch tax revenue}

It is obviously in the best interests of the coastal states to minimize the net loss due to catch taxes on vessels carrying their flag and to maximize the profits available for redistribution. It is assumed that only coastal States in whose waters fish are taken will benefit from any redistribution. The most obvious way to redistribute taxes would be to deduct management costs from 
accumulated taxes and to distribute the remainder according to the percentage of the revenue raised within the 200 mile zone of each coastal State, i.e. according to the catches from each zone. This would account for all the revenue earned within the exclusive economic zones of coastal states. One major issue which will be raised will be whether regional management costs should be deducted before or after the redistribution of taxes raised from vesse1s fishing inside their own 200 mile zone but outside the 12 mile zone. Steps must be taken to ensure that sufficient revenue is available for management, particularly in future years when more and more vessels currently under foreign flags become registered in coastal States.

It may also be necessary to base disbursement on the average catch taken from each 200 mile zone over, say, a four-year period, to reduce the uncertainties in returns due to the extreme fluctuations in the magnitude and distribution of tuna abundance which occur from year to year.

The second issue would be the redistribution of taxes collected for catches made within the region but outside the 200 mile zone, assuming that the regional body does have responsibility for management in such areas. One alternative would be to use all, or the greater part, of such revenue to meet the total management costs to the region, thereby making possible some reduction in the taxes charged throughout the region as a whole.

\subsubsection{Surveillance}

Acceptance of the need to manage a fisheries resource almost always implies the imposition of some form of restriction or regulation of the parties engaged in harvesting this resource. By definition then it may prevent at least some of the participating parties from fully achieving their objectives (which are in most cases monetary, or other material, gains). It is the role of management therefore to examine differences between parties with conflicting interests and to adopt schemes designed to provide maximum protection of each of the parties involved in the fishery, while providing maximum satisfaction to all parties.

The need for a regional fisheries body for the central and western tropical Pacific has been discussed in section 4, and arguments for such a body to be involved in management, at least to the extent of formulating alternative proposals, have been presented in section 5.1.3. Given that the highly migratory resources currently harvested from the region realize more than $\$ U S 250,000,000$ as fresh $f$ ish and generate more than $\$ U S 700,000,000$ worth of secondary industry per annum, and that there are conflicting interests between coastal States and extra-regional fishing nations, an enforcement and surveillance system will obviously be required to ensure adequate management.

The problems of enforcement are extremely delicate, for, as Joseph and Greenough (1977) point out, "enforcement gets into the very sensitive area of national sovereignty". A great deal of consideration will have to be given to the requirements of other fishing nations, both from within and outside the region in order to achieve a workable enforcement procedure. 
One can fairly safely assume that enforcement will remain the responsibility of the contracting parties to any regional agreement; however, the necessity to ensure regional cooperation in the management of the highly migratory resources of the area strengthens the case for a regional body to administer the survelllance of vessels operating within the region.

Figure 3 shows the complexity of the boundaries of the numerous zones of extended jurisdiction in the central and western tropical Pacific. The simplicity of the boundary of the area in which the South Pacific Commission works is shown in figure 1 . Arguments for regional management covering the whole area indicated in this latter figure have previously been given. The same arguments apply to make adoption of a surveillance plan for the one large regular area, rather than numerous smallex, less well-defined ones, more appropriate. In a regional approach the total length of boundary to be covered is greatly decreased and the number of surveillance organizations required is reduced from twenty, to one. Accordingly, costs would be reduced. When it is considered how very limited are naval or aerial surveillance facilities in the developing countries of the region, it is obvious that most countries would be unable to detect the presence of foreign fishing vessels by conventional means, or at least would be almost entirely dependent upon external assistance for such services. Apprehension of offenders would be virtually impossible in most cases.

In addition to minimizing the workload involved in survelllance by adopting a regional approach to the problem, it is clear that the countries of the central and western Pacific will need to adopt nonconventional methods for the surveillance of the huge oceanic areas involved. Joseph and Greenough (1977) have considered the problems of surveillance in the eastern Pacific Ocean and they point out that "Determining positions of vessels at sea could be accomplished easily and effectively using satellite technology. A small radio transponder could be placed aboard each vessel at a modest cost. This 'black box' transponder would be interrogated frequently using existing satellite technology. The resulting data would be relayed to a shore base where each vessel's position could be fixed to within five miles".

A system of satellite surveillance of tuna fishing vessels would be more difficult to operate in the central and western tropical Pacific than the eastern Pacific, firstly because there are many more vessels participating in the fisheries of the western Pacific and, secondly because the area over which these vessels operate is much greater. A satellite surveillance system as outlined by Joseph and Greenough can only work if all cooperating countries, both coastal and foreign, ensure that all vessels fishing in the region carry the necessary 'black box' transponder.

The introduction of a regional satellite surveillance system would not entirely obviate the need for involvement of naval and aerial support. In order to apprehend offenders at least limited patrol activities would still be required. Obviously there are problems involved in obtaining the cooperation of foreign fishing nations in this surveillance scheme but if fishing vessels of only those nations who cooperate are allowed anywhere within the region, and if penalties for offenders are severe enough, then the chances of success are greatly increased. Experience in other parts of the world 
suggests that the chances are further enhanced if a regional fisheries commission is established (see section 5.2) in which both coastal and foreign fishing nations are represented.

There are very few alternatives available to the developing countries of the central and western tropical Pacific in the way of surveillance systems. A satellite system appears to offer by $f$ ar the greatest potential. In addition to surveillance for the enforcement of regulations it has the tremendous advantages of (a) giving excellent data for the determination of the exact location of $f$ ish catches and thus for the management of resources in both coastal and open ocean areas and (b) providing invaluable data for the redistribution of the accumulated catch taxes or other revenues. Furthermore it would be cheap to operate (see section 6) when compared with other surveillance methods. Implementation of such a satellite system does not appear by any means to present insurmountable problems. Detailed modelling and costing of such systems would be one of the most pressing tasks of any regional fisheries agency.

It must be remembered that adoption of a satellite surveillance system, even if completely successful in determining the position of all sizeable fishing vessels in the region, will not in itself solve the problems of enforcement. Detection of offenders is only one aspect of enforcement procedure. If a regional fisheries agency was formed to act only in an advisory capacity to the developing countries of the region, then separate policies and procedures for dealing with vessels violating regulations would be required. Legal action against offenders and determination of penalties would remain the responsibility of the individual coastal state in whose waters offenders were apprehended. If a regional commission was initiated with participation by all countries fishing in the common area, or for common stocks, then violations by individual vessels would be reported to the respective contracting party and legal action would be its responsibility, even if the party was a nation outside the region. It would be the responsibility of the contracting parties to the commission to ensure that the management policies of the commission were adequately enforced by all members.

\subsection{A possible approach to the development of a regional fisheries body}

Broadly there are two problems which must be attacked. Firstly, there is the problem of ensuring that the stocks of fish are not irreparably damaged, while at the same time avoiding economic wastage by underfishing. The combined effort of the fishing vessels participating in each of the fisheries must attain levels of maximum sustainable yield. The second problem is to ensure that the coastal States of the region increase their participation in the fisheries of the region and that they control the direction of the ongoing development of these fisheries, for not to take on this control function would render declarations of exclusive economic zones quite meaningless.

An expedient way of dealing with these problems would be to employ a multiphasic approach to the establishment of the regional fisheries management body proposed earlier.

Under phase 1 a small team comprising full-time professional biologists and economists with access to relevant data collected within the region could draw up interim proposals for management of the resources. These proposals would be submitted to the member governments (the developing 
countries and territories of the region) for consideration. In addition, to ensure the ongoing management of the resources, the regional body would need to establish and maintain a research capacity to study the fisheries as they develop and to advise on further development.

Phase 2, designed to follow phase 1 , would only be initiated if it was recommended as a result of phase 1 and agreed to by the member countries of the region. Phase 2 would commence management and licensing procedures. At this stage it would be essential to bring all nations engaged in fishing in the region into a single commission, for the success of a fisheries management scheme for the region would depend not on $1 y$ on cooperation of intraregional countries but also on countries from outside the region.

After the establishment of phase 2, a further phase, phase 3, would incorporate the survelllance network.

A multiphasic approach along these lines would provide economy in terms of both manpower and finance, and would give the kind of flexibility to the whole scheme of regional fisheries cooperation essential to any multinational group. From very simple beginnings, a body able to administer and manage the complex problem of regional fisheries resources could develop, and during its formation the participating countries could, if necessary, opt for a different line of development.

\section{The Membership, Structure and Financing of a Regional Fisheries Body}

\subsection{Membership}

In the preceding sections of this paper the need for a regional approach to $f$ isheries management in the central and western tropical Pacific has been shown and the advantages in forming a regional fisheries agency to coordinate the development and research of the oceanic resources have been indicated. The need to have the involvement of all the countries and territories of the core area (figure 1) in any regional fisheries management body has been repeatedly stressed. A three-phase approach to the formation of a regional agency has been suggested in section 5.2 and, accordingly, the membership of the agency in each of its phases can be considered on a multiphasic basis.

As the organization indicated for phase 1 is intended primarily to advise the developing Island countries and territories of the region on the development and management options available to them, it is essential that the proposed agency should include all those Island States in the common interest group discussed in section 4.2.7 - 4.2.10. The Island members of the South Pacific Conference and the members of the South Pacific Forum have already indicated their common interest in establishing a regional fisheries agency and all members of both groups should be encouraged to participate.

Progression into phase 2 would necessitate expansion of the membership to incorporate initially all coastal states whose exclusive economic zones harbour substantial portions of a common resource for at least part of the life cycle of the species concerned, i.e. all resource adjacent nations. The countries obviously included in this category would be the Asian coastal States of the western Pacific. 
An additional group to be involved in all management procedures of phase 2 or 3 would be all nations, other than coastal ones, which exploit the resources under management.

\subsection{Structure}

When considering the possible structure of a fisheries agency for the central and western tropical Pacific one should review the structure and functions of existing, similar fisheries organizations. Four international organizations currently are concerned with the research and/or management of tunas and highly migratory species. Of these, two - the Inter-American Tropical Tuna Commission (I-ATTC) and the International Commission for the Conservation of Atlantic Tunas (ICCAT) - are actively involved in management, while the Indo-Pacific Fisheries Commission (IPFC) and the Indian Ocean Fisheries Commission (IOFC) merely provide a forum for discussion of fisheries matters of common interest and for establishing guidelines for cooperation in fisheries development. Only I-ATTC has its own permanent research staff, the other three relying for scientific input for consideration by the member countries on meetings of panels of experts or the presentation of national viewpoints. ICCAT does have a permanent secretariat but its tasks are limited to the compilation and presentation of data and to the administration of the Commission's meetings and working parties.

Joseph (1973) considered the advantages and disadvantages of international fisheries bodies having their own scientific personnel in relation to the four existing organizations and their success in dealing with the problems at that time. He concluded that because of the variable technological development of tuna fishing nations and the widespread distribution of the resources, fleets and markets, fisheries bodies could attain their objectives more efficiently if they maintained an independent research staff. Considering Joseph's conclusion, and furthermore because few of the developing countries of the tropical central and western Pacific currently maintain sufficient research personnel to represent their interests at the international level or to adequately advise on regional implications of management alternatives, it is unlikely that a regional fisheries body for this region could best represent the developing countries and territories of the area without its own impartial secretariat and independent data compiling and research facilities.

Assuming that the multiphasic approach outlined in section 5.2 is adopted, then the regional $f$ isheries advisory agency envisaged for phase 1 would be responsible for the compilation of statistical, biological and economic data and for the derivation of outlines of development options and management proposals for the developing countries and territories of the area. The structure of the secretariat of such an agency could be similar to that proposed by the Food and Agriculture Organization (FAO) for a similar agency in the IPFC region (IPFC, 1976) as outlined in table 6. If major research programmes are to be undertaken by the agency in response to particular problems that may arise, then the staffing and budgetary estimates would need to be increased as required.

If a regional fisheries commission is to be established to involve coastal and foreign fishing nations in implementing management procedures and in fixing catch quotas for some, or all, of the species concerned (phase 2), then a much larger staff will be necessitated. Research and administrative capabilities similar to those of I-ATTC would be envisaged. 
If the responsibility for surveillance (phase 3 ) is to be included in the functions of a regional fisheries commission, then several additional staff positions and the establishment of a surveillance section within the overall structure of the commission will be required. The impact of incorporating surveillance into the responsibilities of the commission will be more pronounced from a financial viewpoint (see section 6.3) than from any alteration it would cause in the structure or staffing of the commission. However, the possibility that a surveillance network could be established to work in collaboration with, but independent from, the fisheries commission must not be overlooked.

\subsection{Financing}

A preliminary estimate of the costs involved in forming a regional advisory-type agency consistent with phase 1 is given in table 6 . This estimate does not include costs associated with the procuring of office space or furniture and should these not be made available by the contracting parties then additional financing will be required. As the agency envisaged in phase 1 will have no means of generating its own revenue, financing would need to be obtained on an aid or grant basis from the member countries or additional sources.

Progression into phase 2 could increase the budget to the same order as that of I-ATTC, i.e. approximately $\$$ US1,000, 000 per year (I-ATTC 1975), but would also give the fisheries body an opportunity to be self-sufficient, meeting its own running costs from the revenue realized from license fees or catch taxes as discussed in section 5.1.5.2.

Incorporation of surveillance facilities into the fisheries agency could more than double the costs involved. If a satellite system is adopted (see section 5.1.6) and the cost of the 'black box' transponders is met by the individual vessels or member countries, but not by the fisheries agency, then additiona 1 costs might be of the order of $\$$ US2,000,000. One of the tasks undertaken in phase 1 would be to ascertain the costs of such a system but, from preliminary figures $I$ have obtained, it appears that total costs in phase 3 could be kept to approximately 20 per cent of the revenue generated from the catch tax system previously discussed. 


\section{REFERENCES}

Allen,R.R.(1975). The conservation of marine animals. Search, 6 No.8: 317-322.

Alverson,D.L.(1973). Science and fisheries management. Presented at Natural Resources Public Policy Seminar, University of washington, Seattle, April 28, 1971. (In press). Cited by Alverson and Paulik (1973).

Alverson,D.L. and G.J.Paulik(1973). Objectives and problems of managing aquatic living resources. Journal of the Fisheries Research Board of Canada, 30: 1936-1947.

Anon (1958). Convention on fishing and conservation of the 1iving resources of the high seas. United Nations Conference on Law of the Sea. Geneva, 29 April, 1958. [United Nations, Geneva, 1958].

Anon (1976a). The present status of the alfonsin, Beryx splendens, fishery in the Midway fishing grounds. Excerpts from Suisan Sekai, 25 No.8: 28-32. August 1976. Translated from the Japanese by Tamio Otsu, Southwest Fisheries Center Honolulu Laboratory, National Marine Fisheries Service. Translation No.18. NOAA, Honolulu, Hawaii, January 1977 .

Anon (1976b). Report of meeting: Ad hoc Meeting of Scientists to Discuss Skipjack Fisheries Developments and Research Requirements, Noumea, New Caledonia, 6-10 December 1976. South Pacific Comission, Noumea, New Caledonia, 1976.

Anon (1977a). 200-mile limit foreign fishing fees proposed. Fishery Market News Report, P-2:3 (January 5, 1977). U.S. Dept. of Commerce, NOAA, NMFS, Statistics and Market News Division, Terminal Island, California, U.S.A.

Anon (1977b). Japan submits counter proposal on 200-mile zone fee schedule. Fishery Market News Report, P-16:4 (February 7, 1977). U.S. Dept. of Commerce, NOAA, NMFS, Statistics and Market News Division, Terminal Island, California, U.S.A.

Chapman,W.M. (1963). World-wide tuna research planning. FAO Fisheries Report, (6) vo1.3: 1097-1107.

Christy,F.T.(1972). Fisheries management and the law of the sea. In Economic Aspects of Fish Production : International Symposium on Fisheries Economics, Paris,29 November-3 December 1971. Organization for Economic Co-operation and Development, Paris, 1972 , pp.4-39.

Department of Primary Industry, Papua New Guinea (1977). The skipjack tuna fishery in Papua New Guinea: 9th Regional Technical Meeting on Fisheries, 24-28 January 1977. South Pacific Commission, Noumea, New Caledonia, 1977.

FAO (1975). Catches and landings. Yearbook of Fisheries statistics, 38,1974 .

Fujino,K. (1972). Range of the skipjack tuna subpopulation in the western Pacific Ocean. In Proceedings of the Second Symposium on the results of the cooperative study of the Kuroshio and adjacent regions,Tokyo, Japan, September 28-October 1,1970, edited by K. Sugawara. Satkon Publishing Co., Tokyo, Pp.373-384. 
Hirth,H.F.(1971). Synopsis of biological data on the green turtle Chelonia mydas (Linnaeus) 1758. FAO Fisheries Synopsis 85.

Hodgkinson,P.W.(1973). Statistical Bulletin No.l Population 1972. South Pacific Commission, Noumea, New Caledonta, 1973.

I-ATTC (1975). Annual report of the Inter-American Tropical Tuna Commission, 1974. Inter-American Tropical Tuna Commission, La Jolla, California, U.S.A., 1975.

I-ATTC (1976). Bi-monthly report, November-December 1976. Inter-American Tropical Tuna Comnission, La Jolla, California, U.S.A., 1976.

IPFC (1976). An immediate management programme for tuna in the IPFC/IOFC region. IPFC Seventeenth Session, Colombo, Sri Lanka, 1-5 November 1976: [Paper] IPFC/76/11. [Bangkok, 1976].

JAMARC (1973). Surveys of trawling grounds in the north central Pacific Ocean, 1972 Season. JAMARC Report No.7, March 1973.

Translated from the Japanese by Tamio Otsu, Southwest Fisheries Center Honolulu Laboratory, National Marine Fisheries Service Translation No.19. NOAA, Honolulu, Hawai1, February 1977.

James,R.H. (1977). Country Statement : Solomon Islands: 9th Regional Technical Meeting on Fisheries, 24-28 January 1977: Working Paper 22. South Pacific Commission, Noumea, New Caledonia, 1977.

Joseph,J. (1973). Scientific management of the world stocks of tunas, billfishes, and related species. Journal of the Fisheries Research Board of Canada, 30: 2471-2482.

Joseph,J.and J.W.Greenough (1977). Alternatives for international management of tuna resources. Inter-American Tropical Tuna Commission, La Jolla, California, U.S.A. (In press).

Kearney,R.E.(1975a). Studies on skipjack in the Pacific: the stock structure of skipjack resources and the possible implications on the development of skipjack fisheries in the central and western Pacific. FAO Fisheries Technical Paper 144: 59-69.

Kearney,R.E.(1975b). Some developments in the tuna fisheries in the Indian Ocean. Indian Ocean Programme Technical Paper, 75/6. FAO, Rome, 1975.

Kearney,R.E. (1976a). A regional appraach to fisheries management in the South Pacific Commission area. Paper presented to the South Pacific Forum Meeting on the Law of the Sea, Suva, 13-14 October 1976. South Pacific Commission, Noumea, New Caledonia, 1976. Also pub1ished as 9th Regional Technical Meeting on Fisheries, 24-28 January 1977: Working Paper 1.

Kearney,R.E.(1976b). Some hypotheses on the skipjack resources of the Pacific Ocean. Ad hoc Meeting of Scientists to Discuss Skipjack Fisheries Developments and Research Requirements : Noumea, New Caledonia, 6-10 December 1976: Working Paper 5. South Pacific Commission, Noumea, New Caledonia, 1976.

Kearney,R.E.(1976c). The expansion of fisheries in Papua New Guinea : prospects and problems. [Paper] for Waigani Seminar., 3-7 May 1976, Papua New Guinea. South Pacific Commission, Noumea, New Caledonia,1976. - also in loth Waigani Seminar, University of Papua New Guinea, Port Moresby. (In press). 
Kearney,R.E.(1977). An estimation of Papua New Guinea's tuna fisheries potential. (In press).

Lever,R.J.A.W.(1964). Whales and whaling in the western Pacific. South Pacific Bulletin, 14 No.2: 33-36.

RSNT (1976). Revised single negotiating text. United Nations Third Conference on the Law of the Sea: A/Conf.62/WP.8/Rev.1. 6 May 1976. QNew York 1976].

Saila,S.B. and V.J.Norton (1974). Tuna : status, trends and alternative management arrangements. Program of International studies of Fishery Arrangements: paper 6. Resources for the Future, Inc., Washington D.C., June 1974 .

Sakiura,H.(1972). The pelagic armorhead, Pentaceros richardsoni, fishing grounds off the Hawailan Islands, as viewed by the Soviets. Suisan Shuko, No.658: 28-31 (June 15, 1972). The article was a translation of an uncited Russian article. Translated from the Japanese by Tamio Otsu, Southwest Fisheries Center Honolulu Laboratory, National Marine Fisheries Service. Translation No.17. NOAA, Honolulu, Hawail, January 1977.

Sasaki,T.(1974). The pelagic armorhead, Pentaceros richardsoni Smlth, in the north Pacific. Bulletin of Japanese Society of Fisheries and Oceanography 24: 156-165. Translated from the Japanese by Tamio Otsu, Southwest Fisheries Center Honolulu Laboratory, National Marine Fisheries Service. Translation No.16. NOAA, Honolulu, Hawaii, January 1977.

Sharp,G.D.(1976). Physiology and environmental restrictions on skipjack tuna. Ad hoc Meeting of Scientists to Discuss Skipjack Fisheries Developments and Research Requirements, Noumea, New Caledonia, 6-10 December 1976: Working Paper 9. South Pacific Commission, Noumea, New Caledonia, 1976.

Shorter Oxford English Dictionary ..., revised and edited by C.T. Onions. 3rd.ed.revised. Oxford, Clarendon Press, 1947. 2 vols.

South Pacific Conference (1976). Report of the Sixteenth South Pacific Conference, Noumea, New Caledonia, 20-29 October 1976. South Pacific Commission, Noumea, New Caledonia, 1976.

South Pacific Forum (1976). Declaration by Members of the South Pacific Forum on Law of the Sea Questions, Suva, 13-14 October 1976. CSouth Pacific Bureau for Economic Cooperation, Suva, 1976].

Sullivan,W.L.(1971). A warning:the decline of international fisheries management looking particularly at the north Atlantic Ocean. In The Law of the Sea : The United Nations and Ocean Management. Proceedings of the Fifth Annual Conference of the Law of the Sea Institute, ed.by L.M.Alexander, Kingston,R.I. The University of Rhode Island: pp.43-8. Cited by Christy (1972).

Tanaka,T. (Undated,a). Atlas of skipjack tuna fishing grounds in southern waters, 1974 fishing season, July 1974-May 1975. Tohoku Regiona1 Fisheries Research Laboratory, Yaizu Branch, Japan. Translated from the Japanese by Tamio Otsu, Southwest Fisheries Center Honolulu Laboratory, National Marine Fisheries Service. Translation No.14. NOAA, Honolulu, Hawaif, April 1976. 
Tanaka,T. (Undated,b). At las of skipjack tuna fishing grounds in southern waters, 1975 fishing season, June 1975-May 1976. Tohoku Regional Fisheries Research Laboratory, Yaizu Branch, Japan. Translated from the Japanese by Tamio Otsu, Southwest Fisheries Center Honoluiu Laboratory, National Marine Fisheries Service. Translation No.15. NOAA, Honolulu, Hawa1i, July 1976.

Tohoku Regional Fisheries Research Laboratory 1974. Atlas of skipjack tuna fishing grounds in southern waters, $1973 \mathrm{fishing}$ season, July 1973-May 1974. Tohoku Regional Fisheries Research Laboratory, Yaizu Branch, Japan. Translated from the Japanese by Tamio Otsu, Southwest Fisheries Center Honolulu Laboratory, National Marine Fisheries Service. Translation No.7. NOAA, Honolulu, Hawaii, July 1974. 
Table 1

Estimated total catches of all tuna and tuna-1ike species in selected statistical areas (Figures modified from W.L. Klawe, Inter-American Tropical Tuna Commission, 1976, Personal Communication).

\begin{tabular}{|c|c|c|c|c|}
\hline $\begin{array}{c}\text { STATISTICAI } \\
\text { AREA }\end{array}$ & 61 & 71 & 77 & 81 \\
\hline $\begin{array}{l}\text { SPECIES } \\
\text { Frigate Tuna } \\
\text { Auxis spp. }\end{array}$ & 27,726 & 20,067 & - & - \\
\hline $\begin{array}{l}\text { Mackerel Tuna } \\
\text { Euthynnus spp. }\end{array}$ & 13,383 & 24,150 & 3,736 & - \\
\hline $\begin{array}{l}\text { Skipjack } \\
\text { Katsuwonus pelamis }\end{array}$ & 129,227 & 283,060 & 89,953 & 1,363 \\
\hline $\begin{array}{l}\text { Albacore } \\
\text { Thunnus alalunga }\end{array}$ & 64,247 & 12,449 & 9,312 & 37,949 \\
\hline $\begin{array}{l}\text { Yellowfin Tuna } \\
\text { Thunnus albacares }\end{array}$ & 28,923 & 56,603 & 218,939 & 16,632 \\
\hline $\begin{array}{l}\text { Southern Bluefin } \\
\text { Tuna } \\
\text { Thunnus maccoyii }\end{array}$ & - & - & - & 13,866 \\
\hline $\begin{array}{l}\text { Blgeye Tuna } \\
\text { Thunnus obesus }\end{array}$ & 7,522 & 21,513 & 36,690 & 15,518 \\
\hline $\begin{array}{l}\text { Bluefin Tuna } \\
\text { Thunnus thynnus }\end{array}$ & 10,255 & 96 & 5,670 & - \\
\hline $\begin{array}{l}\text { Longtail Tuna } \\
\text { Thunnus tonggol }\end{array}$ & - & 13,800 & - & - \\
\hline $\begin{array}{l}\text { Other Miscellaneous } \\
\text { Tuna Species }\end{array}$ & 1,200 & 31,980 & - & - \\
\hline $\begin{array}{c}\text { TOTAL } \\
\text { ALL } \quad \text { TUNAS }\end{array}$ & 282,483 & 463,718 & 364,300 & 85,328 \\
\hline $\begin{array}{l}\text { Swordfish } \\
\text { Xiphias gladius }\end{array}$ & 6,745 & 845 & 2,548 & 1,919 \\
\hline $\begin{array}{l}\text { Marlins, Billfishes } \\
\text { (Istiophoridae) }\end{array}$ & 12,380 & 6,736 & 14,032 & 3,548 \\
\hline $\begin{array}{c}\text { TOTAL TUNAS } \\
\text { SWORDFISH } \\
\text { AND BILLFISHES }\end{array}$ & 301,608 & 471,299 & 380,880 & 90,795 \\
\hline
\end{tabular}


Table 2

Nominal total fish and tuna catches in 1974 by the countries and territories in the South Pacific

Commission area. (From FAO, 1975. Previously published by Kearney, 1976a).

\begin{tabular}{|c|c|c|}
\hline Country or Territory & Total Fish Catch (MT) & Skipjack Catch (MT) \\
\hline American Samoa & 82 & $10 *$ \\
\hline Cook Islands & $1000 \mathrm{~F}$ & $50 *$ \\
\hline Fiji & 4261 & $100 *$ \\
\hline French Polynesia & 2386 & $1000 *$ \\
\hline $\begin{array}{c}\text { Gilbert and E11ice } \\
\text { Island } s^{\star \star \star}\end{array}$ & $300 \mathrm{~F}$ & $50 *$ \\
\hline Guam & 92 & $10 *$ \\
\hline Nauru & - & - \\
\hline New Caledonia & 868 & $30 *$ \\
\hline New Hebrides & $(8000 \mathrm{~F}) \star \star \star$ & $(8000 \mathrm{~F}) \star \star$ \\
\hline Nive & - & - \\
\hline Norfolk Island & - & - \\
\hline Papua New Guinea & 52708 & 40350 \\
\hline Pitcairn & - & - \\
\hline Solomon Islands & 11585 & 10000 \\
\hline Tokelau & - & - \\
\hline Tonga & 726 & $30 *$ \\
\hline TTPI & 3360 & 3206 \\
\hline Wa1lis and Futuna & - & - \\
\hline Western Samoa & 900 & $40 *$ \\
\hline $\begin{array}{l}\text { TOTAL BY SPC COUNTRIES } \\
\text { AND TERRITORIES }\end{array}$ & 78268 & 54876 \\
\hline TOTAL BY FOREIGN FLEETS & UNKNOWN & $145000 *$ \\
\hline
\end{tabular}

* No figures available so rough estimate given.

** Almost al1 tuna caught by foreign long-1ine vessels. Omitted from totals.

*** These figures were compiled by FAO before the emergence of Tuvalu.

F FAO estimate 
$\underline{\text { Table } 3}$

Annual total catch and catch rates by the Papua New Gulnean skipjack fleet. (From Department of Primary Industry, Papua New Guinea, 1977).

Total Catch*

\begin{tabular}{|l|l|l|}
\hline 1970 & 2,430 & 4.76 \\
1971 & 17,002 & 4.19 \\
1972 & 13,124 & 2.67 \\
1973 & 28,269 & 3.68 \\
1974 & 41,780 & 4.40 \\
1975 & 17,322 & 2.69 \\
1976 & 33,035 & 4.23 \\
\hline
\end{tabular}

* All figures in tonnes

\section{$\underline{\text { Table } 4}$}

Annual total catch and catch rates by the Solomon Islands' skipjack fleet. (From the Ministry of Natural Resources, Solomon Islands, unpubl1shed data).

\begin{tabular}{|c|c|c|}
\hline & Total Catch* & Avg. catch per boat per day* \\
\hline 1971 & 4,711 & 5.75 \\
\hline 1972 & 7,885 & 2.35 \\
\hline 1973 & 6,512 & 3.35 \\
\hline 1974 & 10,331 & 4.74 \\
\hline 1975 & 7,142 & 2.95 \\
\hline 1976 & 15,787 & 4.52 \\
\hline
\end{tabular}

* All figures in tonnes 
Table 5 List of highly migratory species. (From Part II of RSNT, 1976)

1. Albacore tuna: Thunnus alalunga

2. Bluefin tuna: Thunnus thynnus

3. Bigeye tuna: Thunnus obesus

4. Skipjack tuna: Katsuwonus pelamis

5. Yellowfin tuna: Thunnus albacares

6. Blackfin tuna: Thunnus atlanticus

7. Little tuna: Euthynnus alletteratus; Euthynnus affinis

8. Frigate mackerel: Auxis thazard; Auxis rochei

9. Pomfrets: Family Bramidae

10. Marlins: Tetrapturus angustirostris; Tetrapturus belone; Tetrapturus pfluergeri; Tetrapturus albidus; Tetrapturus audax; Tetrapturus georgei; Makaira mazara; Makaira indica; Makaira nigricans

11. Sail-fishes: Istiophorus platypterus; Istiophorus albicans

12. Swordf1sh: Xiphias gladius

13. Sauries: Scomberesox saurus; Cololabis saira; Cololabis adocetus; Scomberesox saurus scombroides

14. Dolphin: Coryphaena hippurus; Coryphaena equiselis

15. Oceanic sharks: Hexanchus griseus; Cetorhinus maximus; Family Alopiidae; Rhincodon typus; Family Carcharhinidae; Family Sphyrnidae; Family Isuridae

16. Cetaceans: Family Physeteridae; Family Balaenopteridae; Family Balaenidae; Family Eschrichtiidae; Family Monodontidae; Family Ziphiidae; Family Delphinidae 
Table 6 Estimated budget for a secretariat of a regional fisheries agency (Phase 1). Modified from IPFC (1976).

\section{Personne 1}

Director (Senior Scientist)

Assistant Director (Administrative)

Research Scientist

Economist

Statistician (Data Processing)

Data Processing Assistant

Secretaries (2)

Duty Trave1

Consultants

\section{Miscellaneous}

Printing

Annual Meeting

Temporary Assistance

Computer costs

Incidentals

\section{Cost per year US\$}

44,340

32,160

38,700

38,700

32,160

15,240

30,480

26,500

30,000

40,000

50,000

10,000

8,000

5,000

TOTAL US\$ 401,280 


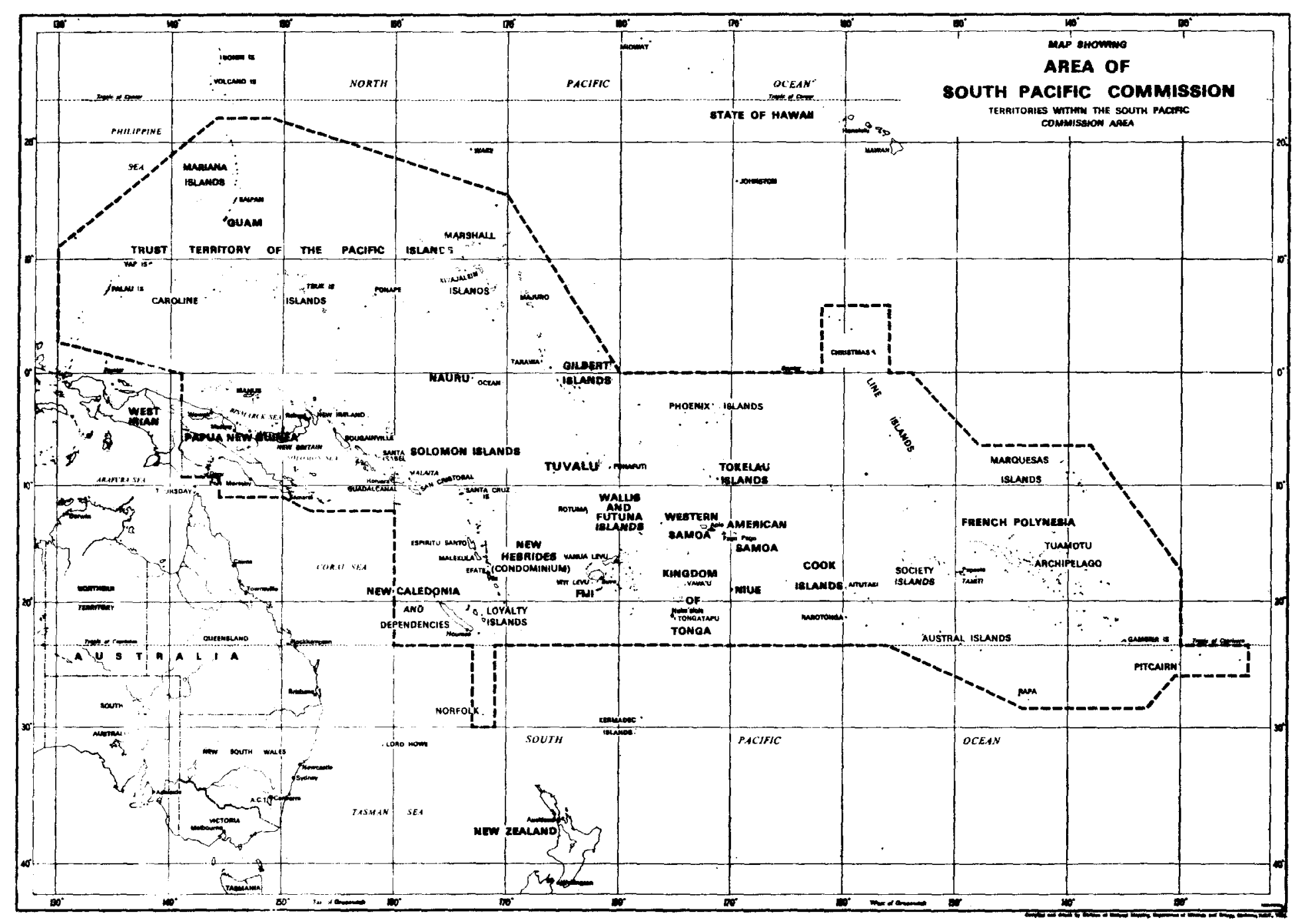

Fig. 1 The core area of the central and western tropical Pacific Ocean. 


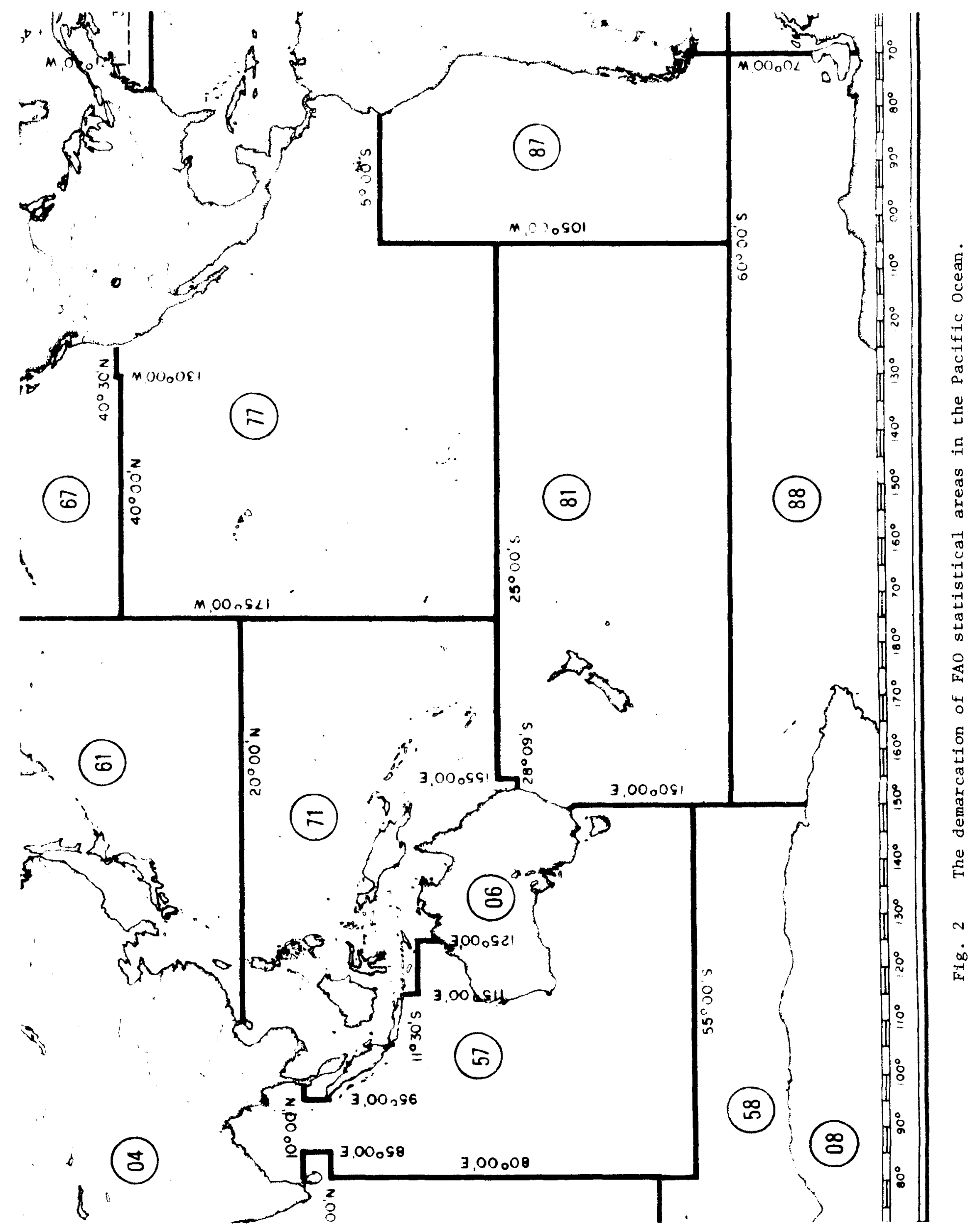




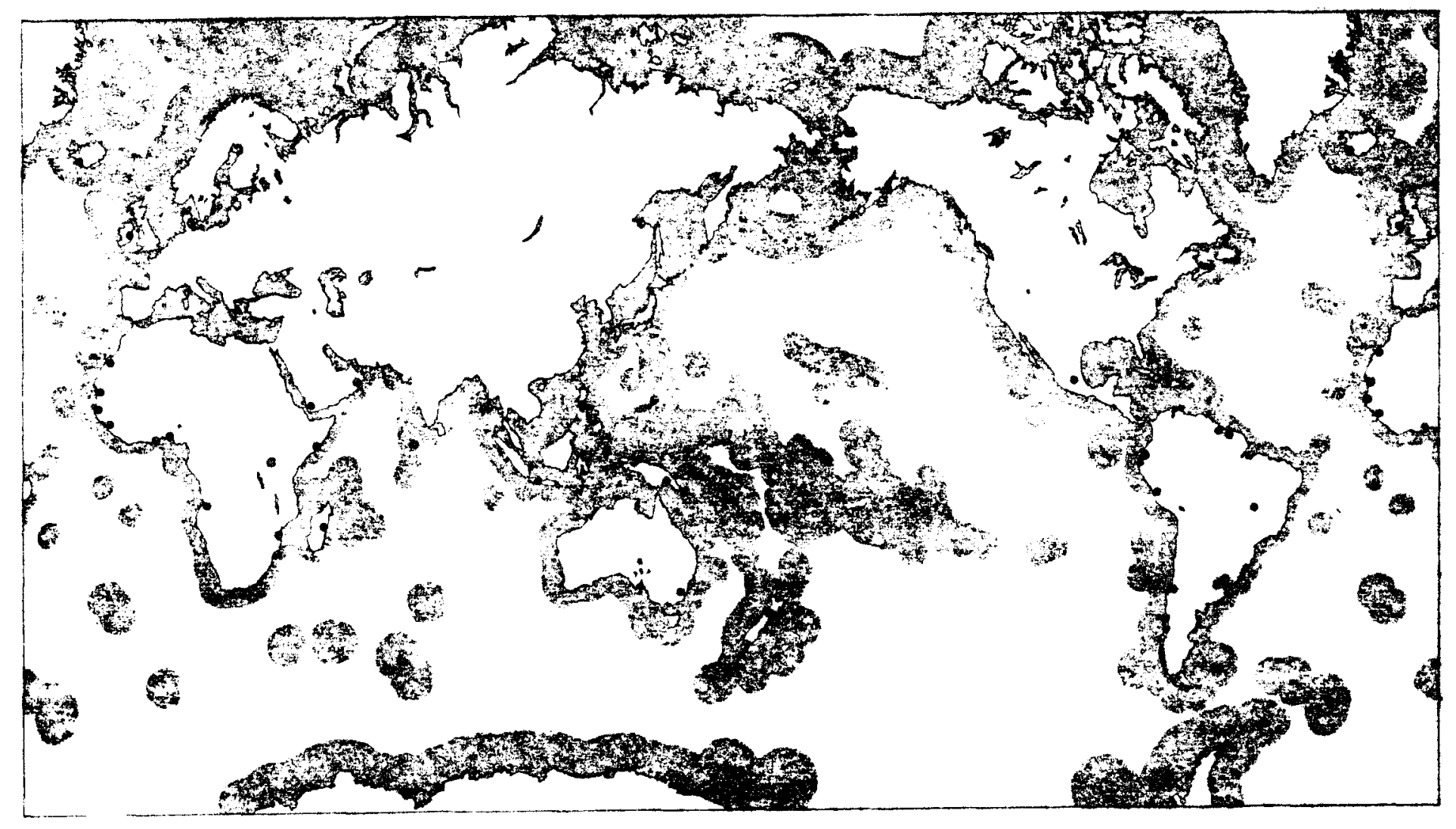

F1g. 3 Approximation of areas of 200 mile exclusive econonic zones. 


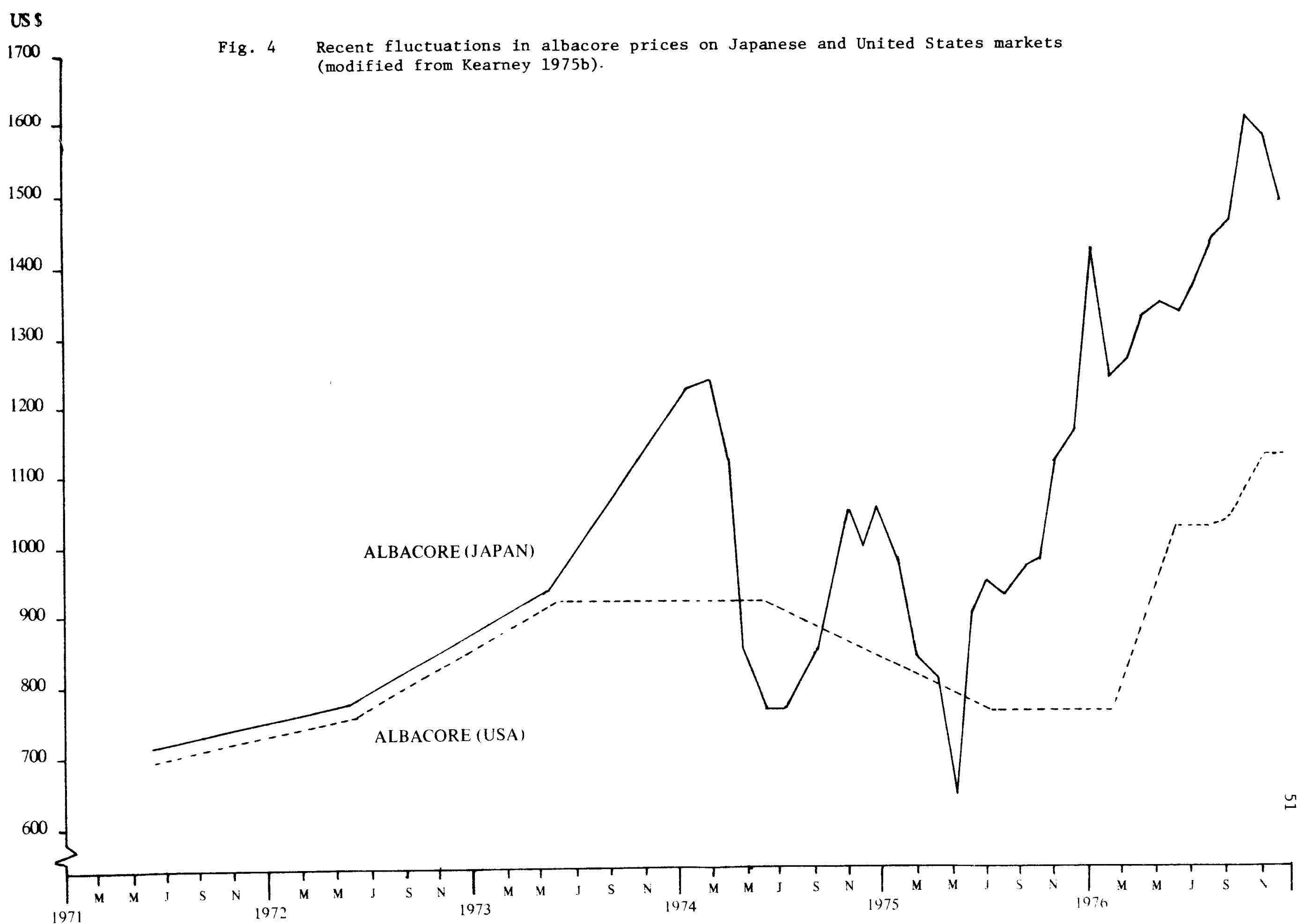




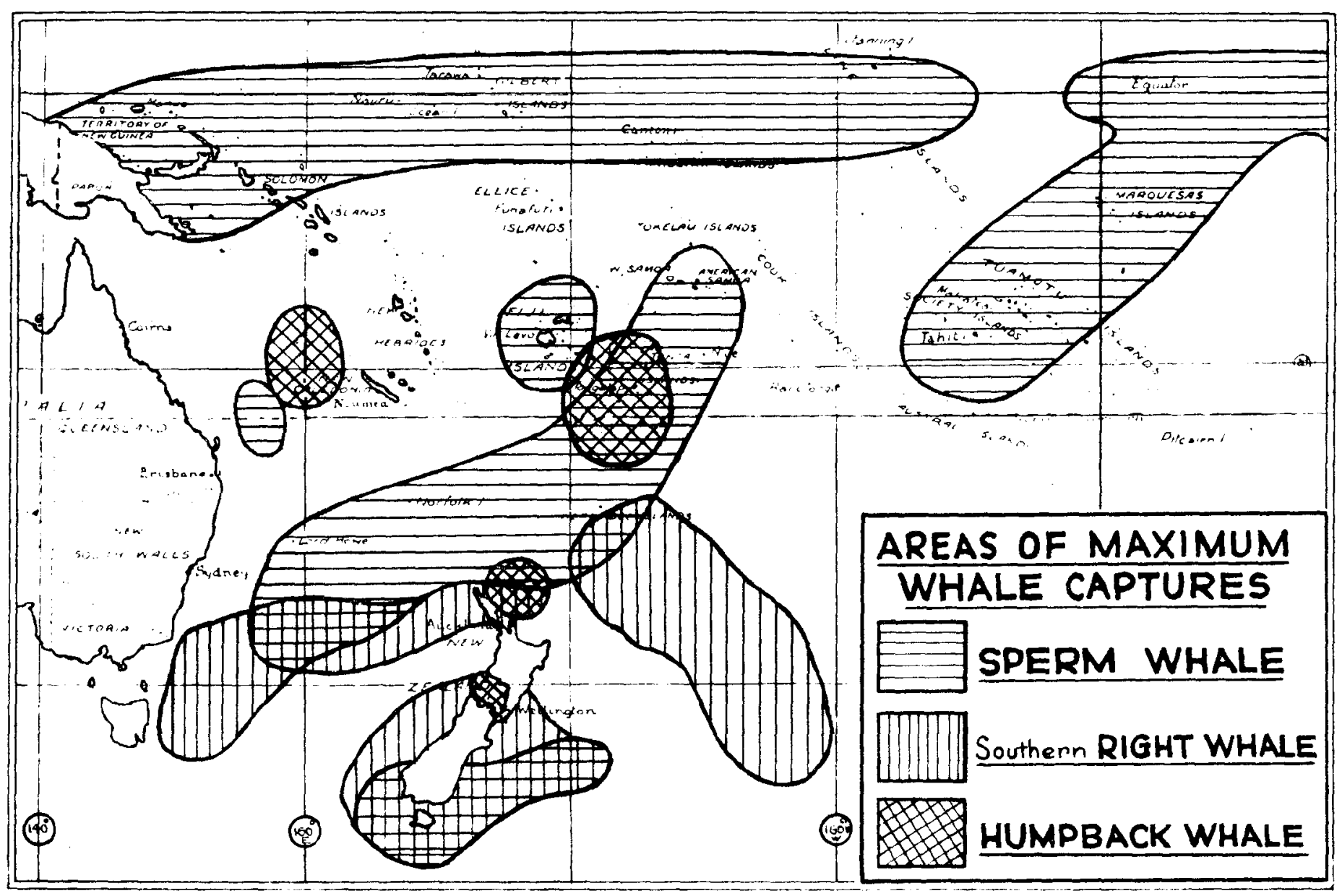

Fig. 5 Areas of maximum whale captures from the south western Pacific in the 19th century. (From Lever, 1964). 